\title{
African Medicinal Plants with Antidiabetic Potentials: A Review
}

Authors

Affiliations
Aminu Mohammed ${ }^{1,2}$, Mohammed Auwal Ibrahim ${ }^{1,2}$, Md. Shahidul Islam ${ }^{1}$

${ }^{1}$ Discipline of Biochemistry, School of Life Sciences, University of KwaZulu-Natal (Westville Campus), Durban, South Africa

${ }^{2}$ Department of Biochemistry, Faculty of Science, Ahmadu Bello University, Zaria, Nigeria

\author{
Key words \\ - Africa \\ - antidiabetic effects \\ - diabetes mellitus \\ - medicinal plants \\ - North Africa \\ - East Africa \\ - West Africa \\ - Central Africa \\ - Southern Africa
}

received August 22, 2013 revised Dec. 31, 2013 accepted January 1, 2014

Bibliography

DOI http://dx.doi.org/

10.1055/s-0033-1360335

Published online February 17, 2014

Planta Med 2014; 80: 354-377

(c) Georg Thieme Verlag KG

Stuttgart · New York .

ISSN 0032-0943

Correspondence

Dr. Md. Shahidul Islam

School of Life Sciences

University of KwaZulu-Natal

(Westville Campus)

Durban 4000

South Africa

Phone: +27312608717

Fax: +27312607942

islamd@ukzn.ac.za

\section{Abstract \\ $\nabla$}

Diabetes mellitus is one of the major health problems in Africa. The conventional oral synthetic antidiabetic drugs available to manage the disease are costly and not readily affordable to the majority of the affected population. Interestingly, the continent is endowed with a tremendous number of medicinal plants that have been explored for their folkloric treatment of diabetes mellitus. Scientific investigations have validated the antidiabetic potentials of a number of these medicinal plants but there is no repository with information on these scientifically investigated plants as a guide for future research. In this review article, all of the in vivo antidiabetic studies

\section{Introduction}

$\nabla$

Diabetes mellitus (DM) is a heterogeneous group of metabolic disorders characterized by persistent hyperglycemia [1] and derangement in the metabolism of carbohydrates, fats, and proteins as a result of defects in insulin secretion and/or insulin action [2].

Recent data from the International Diabetes Federation (IDF) indicates that DM affects over 366 million people worldwide and this is likely to increase to 552 million or even more by the year 2030 [3]. In Africa, more than 14 million people have diabetes, accounting for about $4.3 \%$ of adults and is responsible for about 401276 deaths in 2012 in the region [4]. West Africa recorded the highest number of DM cases with Nigeria (3.2 million diabetics) and Côte d'Ivoire (421 023 diabetics) occupying first and second positions, respectively. In Southern Africa, South Africa tops the list (2.0 million diabetics) followed by the Democratic Republic of Congo (737000 diabetics). Kenya was listed as the fifth country in Africa and the first from the eastern region of Africa conducted between January 2000 and July 2013 on African plants are systematically compiled with a closer look at some relevant plants from the continent's subregions. Plants of the Asteraceae and Lamiaceae families are the most investigated, and West Africa has the highest number of investigated plants. Although promising results were reported in many cases, unfortunately, only a few studies reported the partial characterization of bioactive principles and/or mechanisms of action. It is hoped that government agencies, pharmaceutical industries, and the scientific community will have a look at some of these plants for future research and, if possible, subsequent commercialization.

(720730 diabetics), while Cameroon (517860 diabetics) recorded the highest figure from the central region. North Africa had the least number of diabetics among the African subregions with no single nation in the top ten list of African countries with DM [4].

At present, different approaches are used to control DM using modern synthetic antidiabetic drugs in addition to lifestyle modification. This includes sulphonylureas (glibenclamide), glucosidase inhibitors (acarbose), and biguanide (metformin). However, these synthetic oral hypoglycemic agents have characteristic profiles of serious side effects, which include hypoglycemia, weight gain, gastrointestinal discomfort, nausea, liver and heart failure, and diarrhea [5] in addition to being rather costly and not affordable by the majority of African populations. These limitations coupled with an exponential increase in the prevalence of DM motivate researchers to scientifically validate the folkloric use of a number of antidiabetic African medicinal plants as possible alternative therapies. This is partly because herbs and natural products form an important compo- 


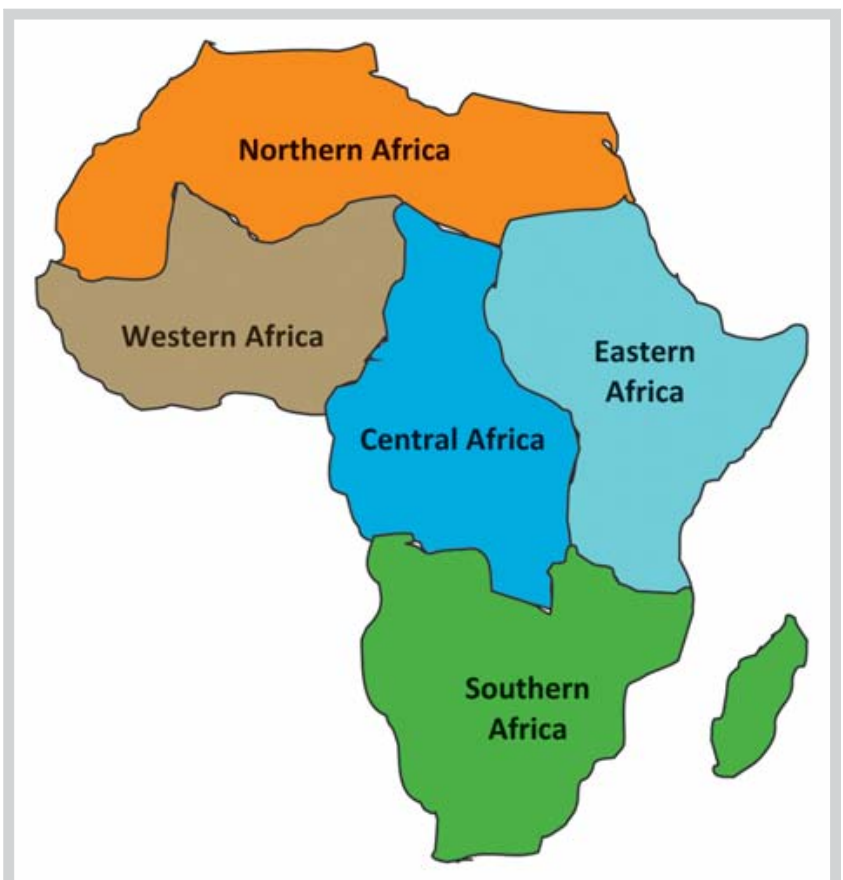

Fig. 1 Map of Africa showing the different subregions. (Color figure available online only.)

nent of the health care delivery system in African countries [6]. According to the World Health Organization (WHO) [7], 80\% of the population in many African countries depend almost entirely on traditional medicines, herbal medicines in particular, for their primary health care needs $[8,9]$. This is attributed to the perceived effectiveness of the plant-based therapies as well as the availability of these medicinal plants because the continent accounts for about $25 \%$ of the total number of higher plants in the world where more than 5400 medicinal plants were reported to have over 16300 medicinal uses [10].

In Africa, herbal medicines are usually provided by a traditional healer, who utilizes natural products in curing many diseases. They have different local methods to diagnose DM in their patients, as they do not rely on laboratory investigations. This is achieved through identifying symptoms like frequent urination, sexual dysfunction, swollen legs, hands and stomach, obesity, fatigue, and profuse sweating during the consultation process. In some cases, they direct the patients to urinate on locally prepared formulations and return after a couple of days with the results of a diagnosis. At present, DM is among the diseases which are most extensively treated with traditional medicines using medicinal plants. This is evident by the propensity of the ethnobotanical surveys for medicinal plants used for the management of DM from different African subregions that include West [11, 12], East [13-15], North [16-18], Southern [19,20], and Central Africa [21]. Interestingly, scientific investigations have confirmed the efficacy of a number of these plant-derived formulations on $\mathrm{DM}$, but presently there is no comprehensive review and/or repository that exists in the literature of these scientifically investigated African antidiabetic medicinal plants that cover the whole of Africa. In this article, we conducted an exhaustive review of all scientifically investigated African antidiabetic medicinal plants whose results have been published between January 2000 and July 2013. The scientific community, government agencies, and

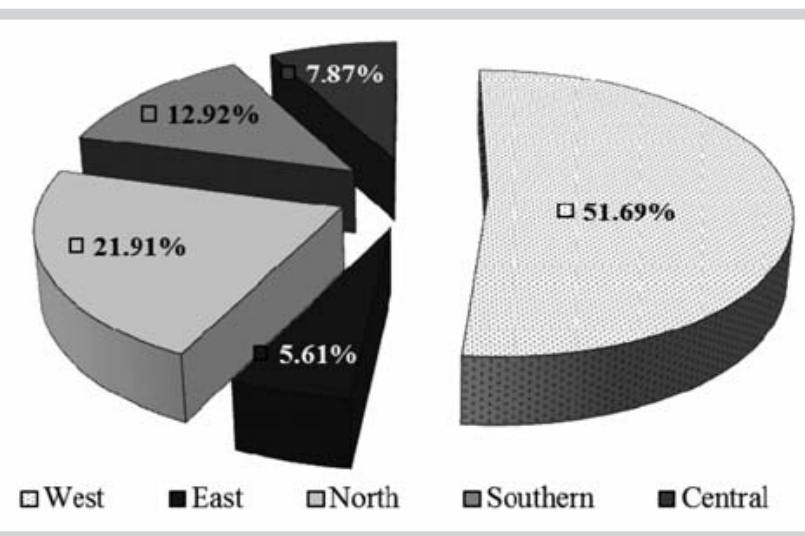

Fig. 2 Subregional distributions of investigated African medicinal plants with antidiabetic effects.

pharmaceutical industries may use this as a possible guide for future research.

\section{Results and Discussion}

$\nabla$

A map of Africa indicating the subregions of the continent as used in this review is presented in 8 Fig. 1. A total of 185 plants species from 75 families in Africa have been investigated for antidiabetic effects. The information obtained on these plants includes scientific and common names, families, parts of the plant used, solvent used, and whether the crude extracts or fractions were used in the course of investigation. From the results, plants from the West African subregion account for $51.69 \%$ of all the plants investigated for antidiabetic potentials in Africa over the period mentioned ( Fig. 2). More than $90 \%$ of all documented plants from this region emanate from Nigeria, with few data from Ghana, Senegal, Benin, Togo, and Côte d'Ivoire ( Table 1). Reports on the antidiabetic effects of North African plants account for 21.91\% ( Fig. 2) and originated from Morocco, Egypt, Algeria, Tunisia, Sudan, and Libya ( Table 3). On the other hand, $12.92 \%$ of antidiabetic African plants were reported from Southern Africa (๑ Fig. 2) with most of the studies originating from South Africa ( Table 4). The remaining parts, East ( Table 2) and Central ( Table 5) Africa, recorded 7.87 and $5.61 \%$, respectively, of African medicinal plants with antidiabetic effects. The results also indicated that plants from the Asteraceae and Lamiaceae families received a lot of attention in all parts of Africa ( Fig. 3). On the other hand, analysis of the investigated parts of the plant indicated that the leaf was the most scientifically investigated part (॰ Fig. 4).

More importantly, promising results were reported in many cases but, unfortunately, only a few studies reported detailed characterization of bioactive principles. Data available indicated that only six plants from northern and two from western regions received partial characterization of a possible active ingredient that could be responsible for their antidiabetic effects ( $\bullet$ Table 6 ). In order to provide a full view of the antidiabetic potentials of these African medicinal plants, the scientifically investigated medicinal plants are categorized into subregions ( $\mathbf{F i g . 1}$ ) and discussed more thoroughly. The discussions are based on the subregions and the criteria used for highlighting a plant that has potency of the reported antidiabetic activity, except in the case of 


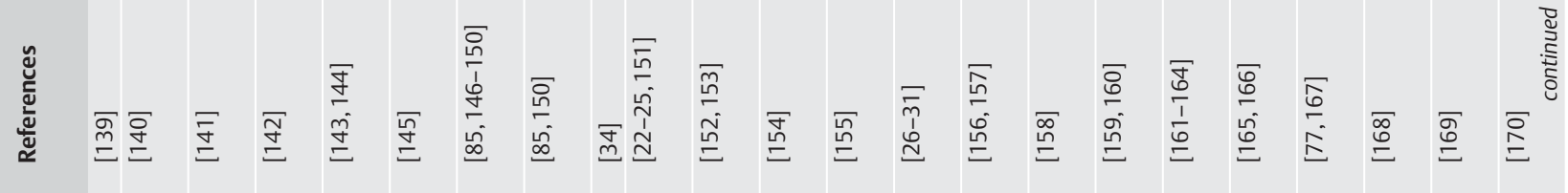

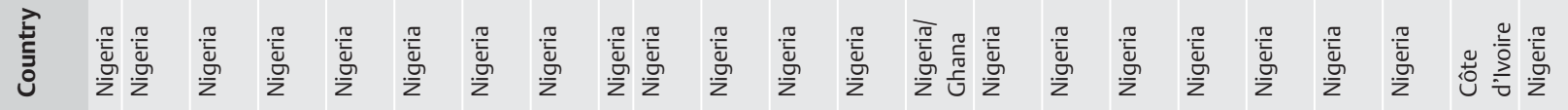

MIIIIIIIIIIIIIIIII!

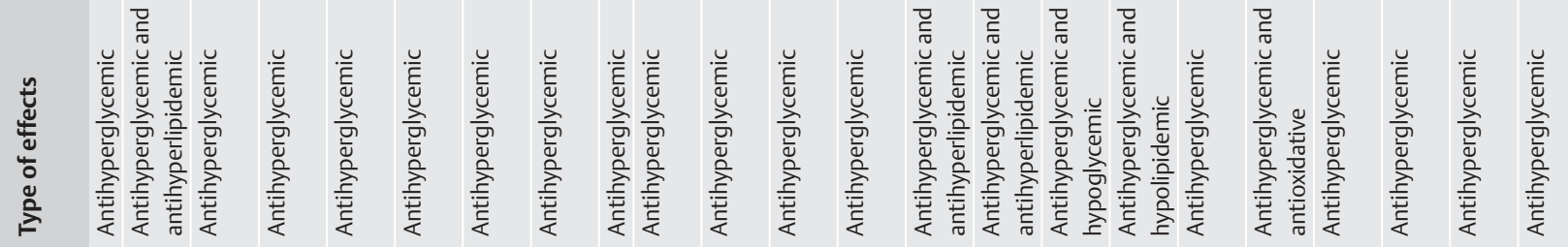

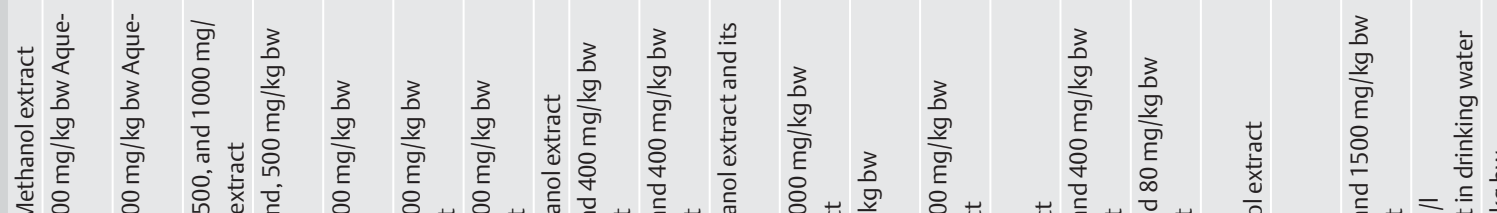

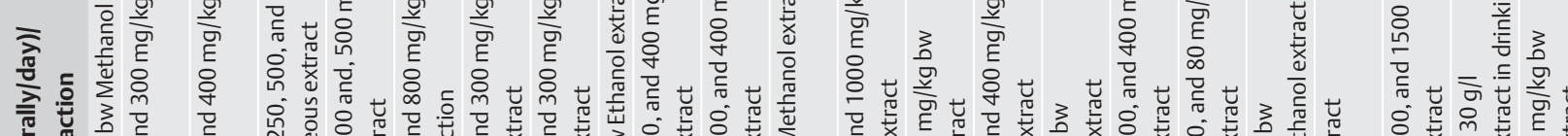

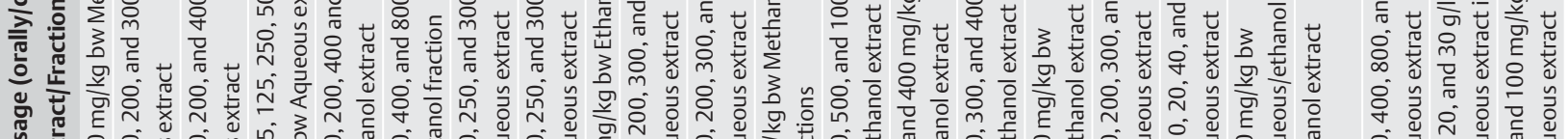

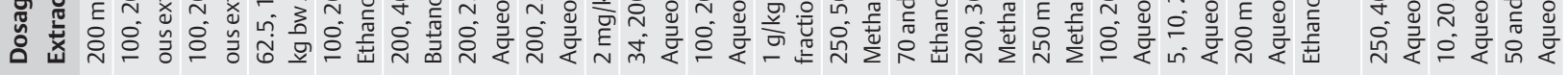

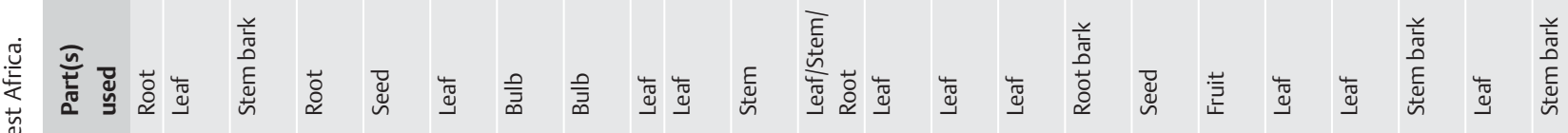

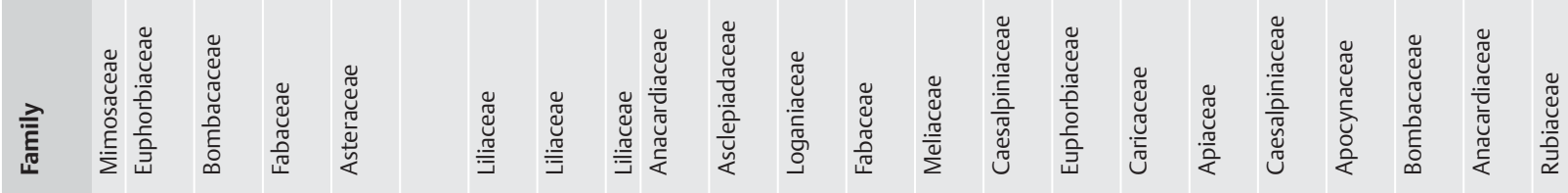

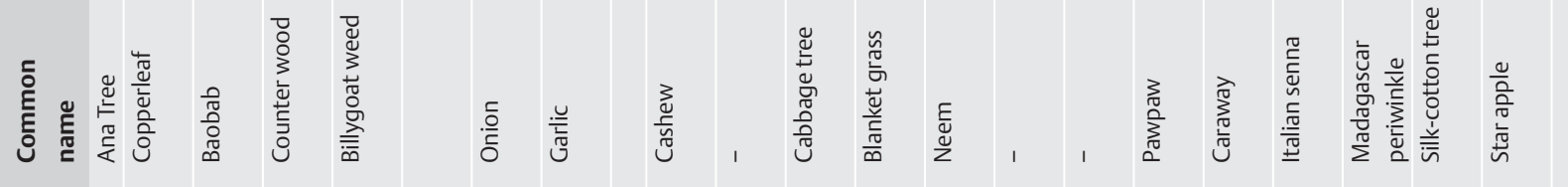

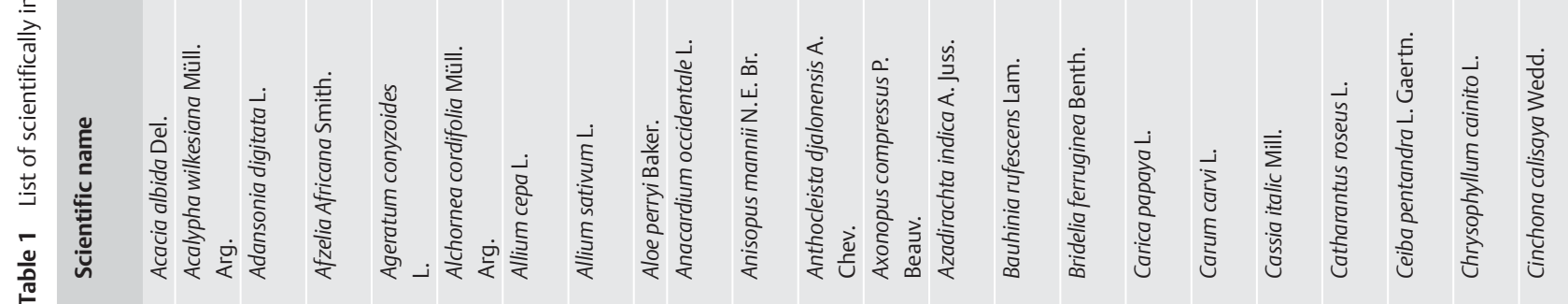


|

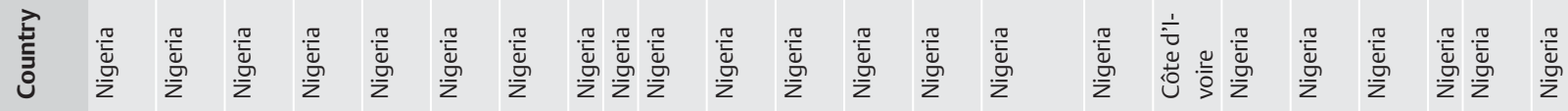

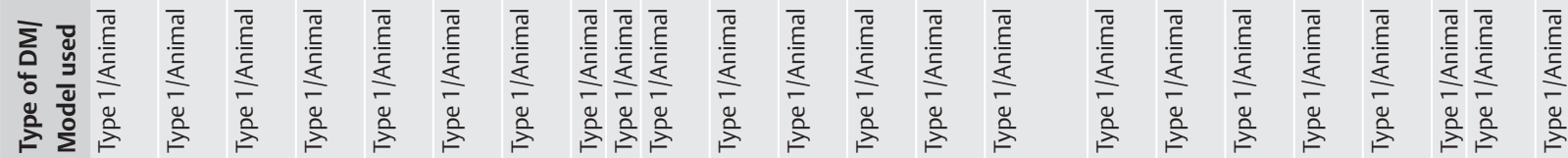

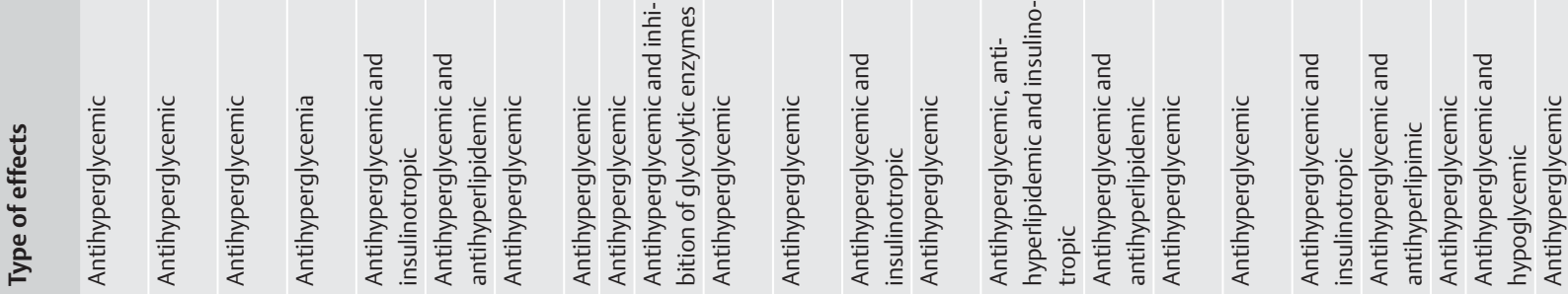

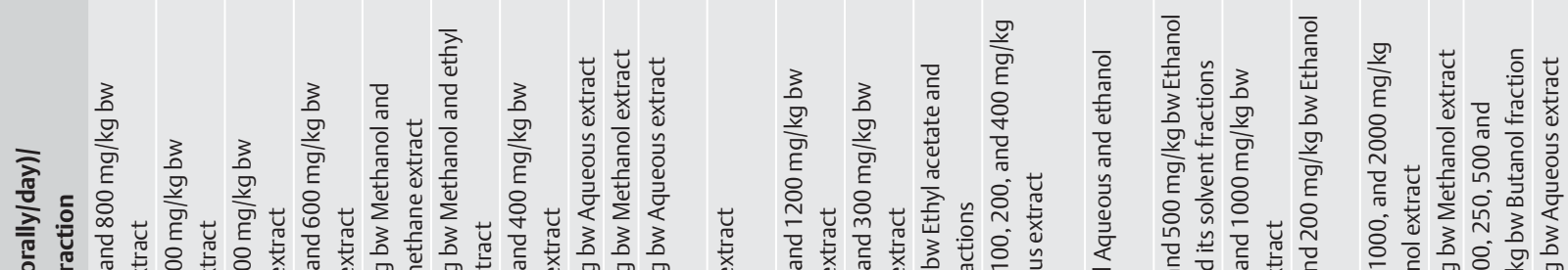

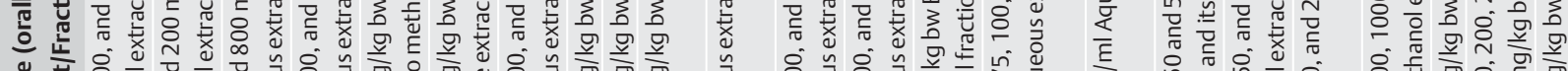

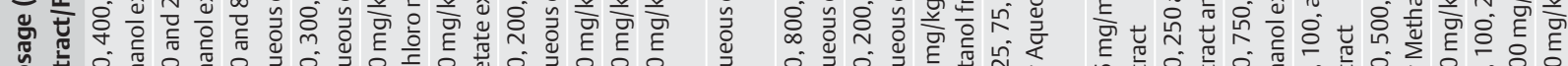

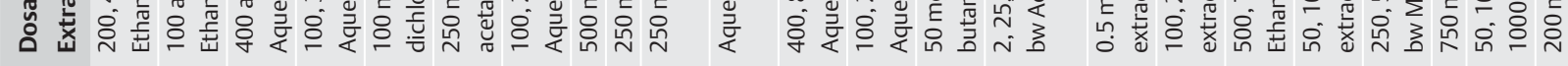

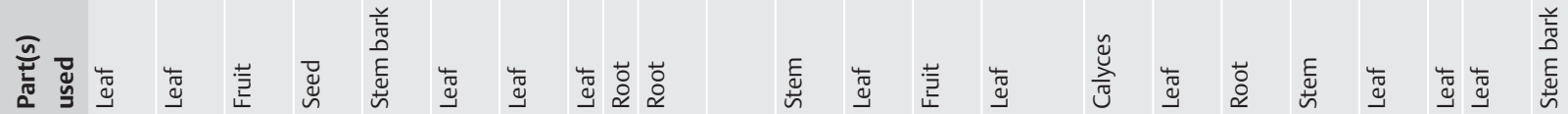

$\Pi\|\Pi\|\|\|\|\|\|\|\|\|$

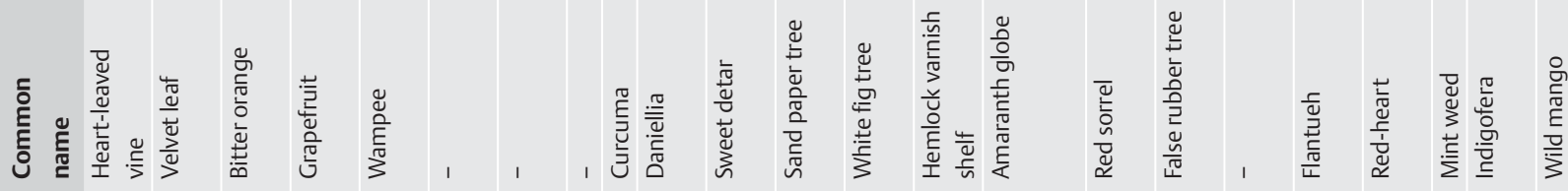

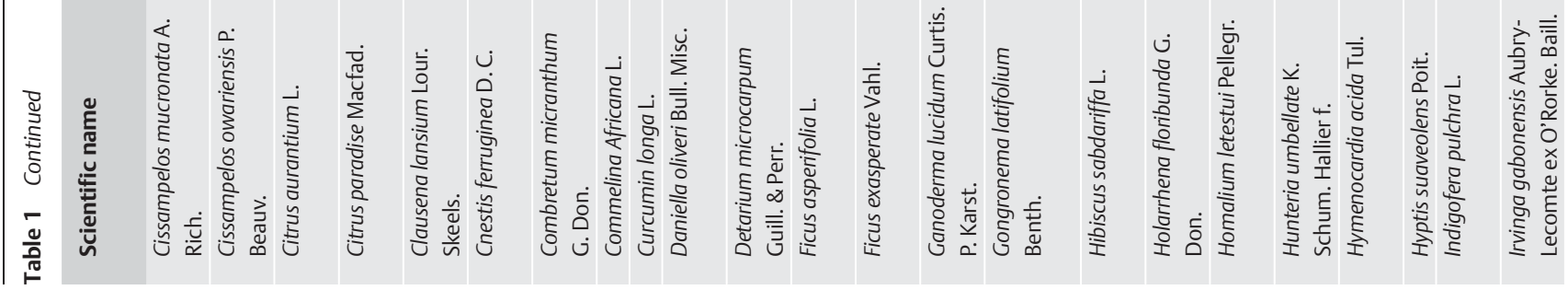




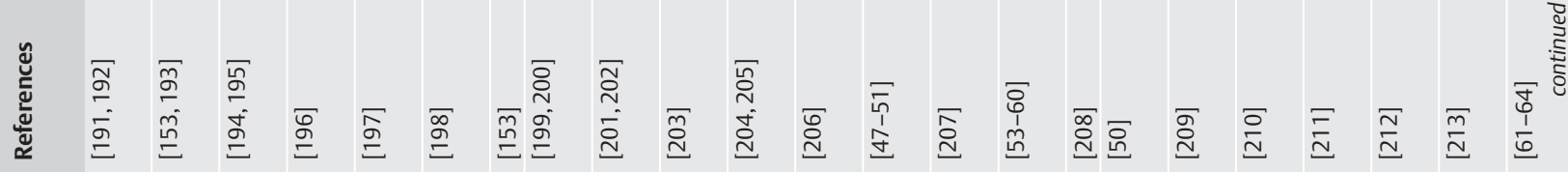

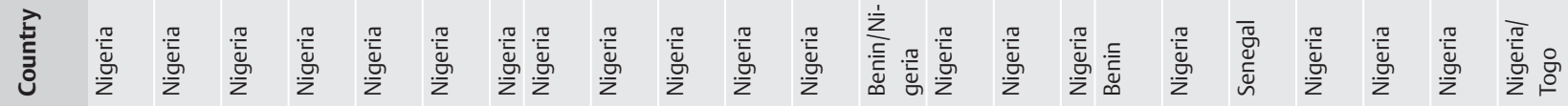

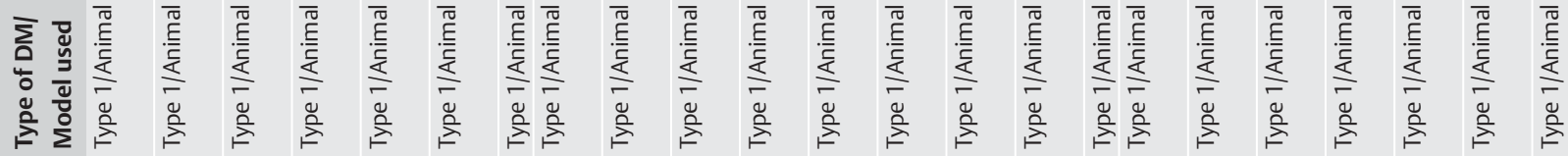

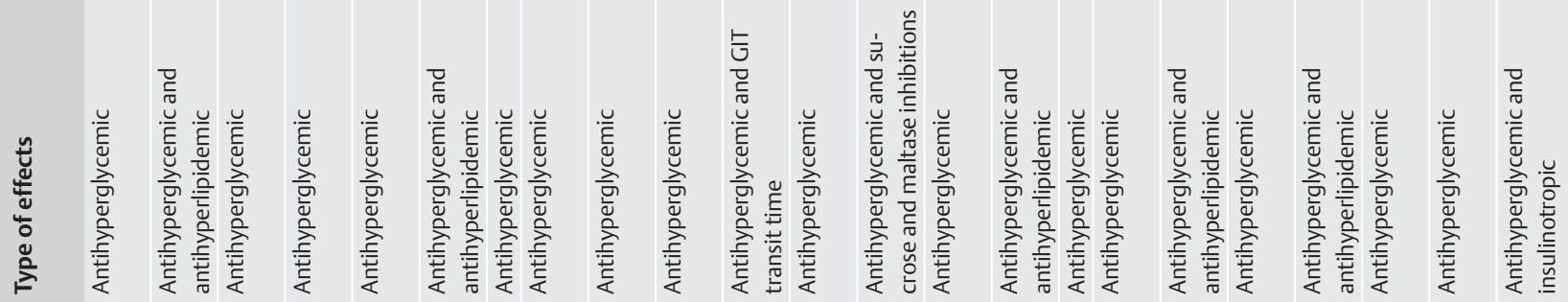

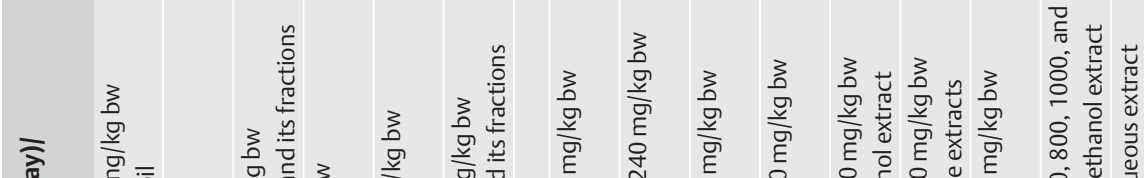

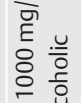

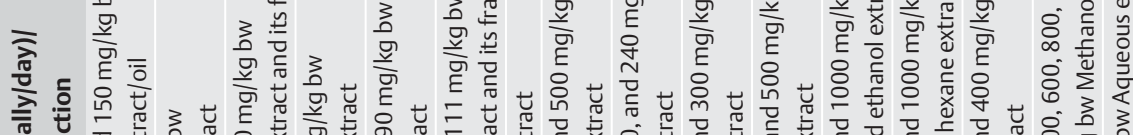

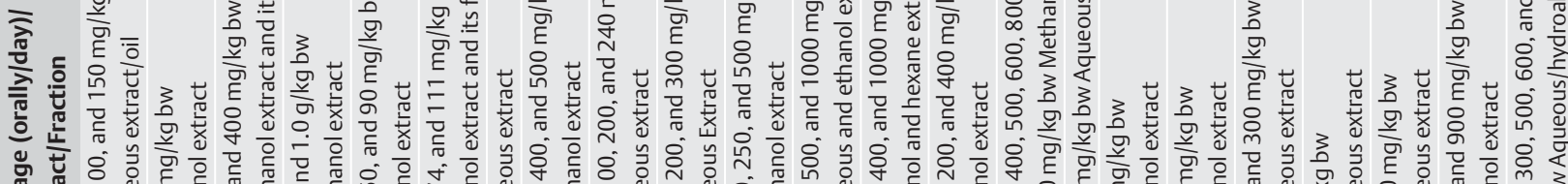

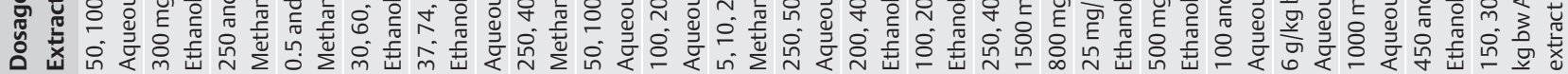

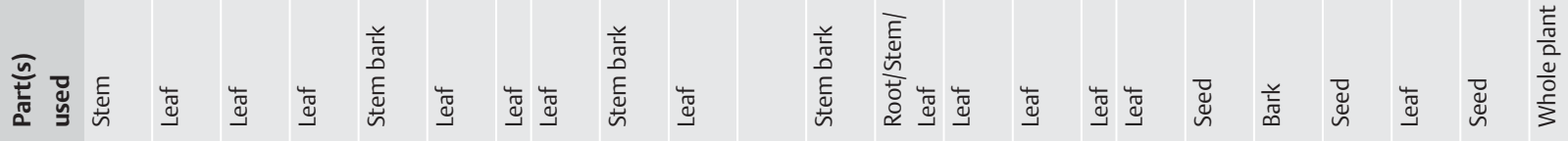

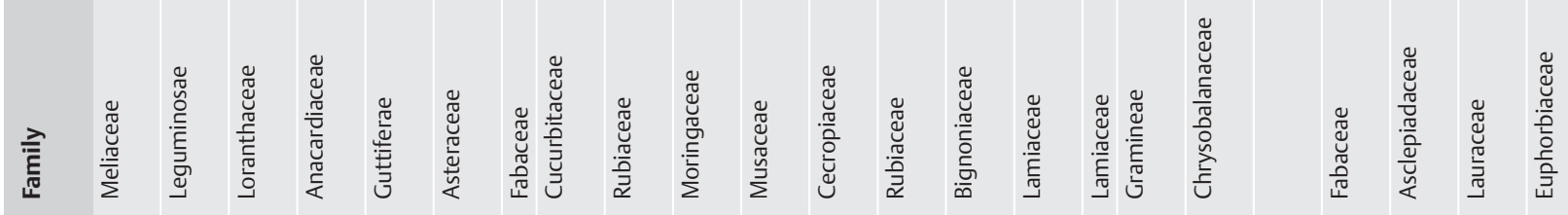

In!

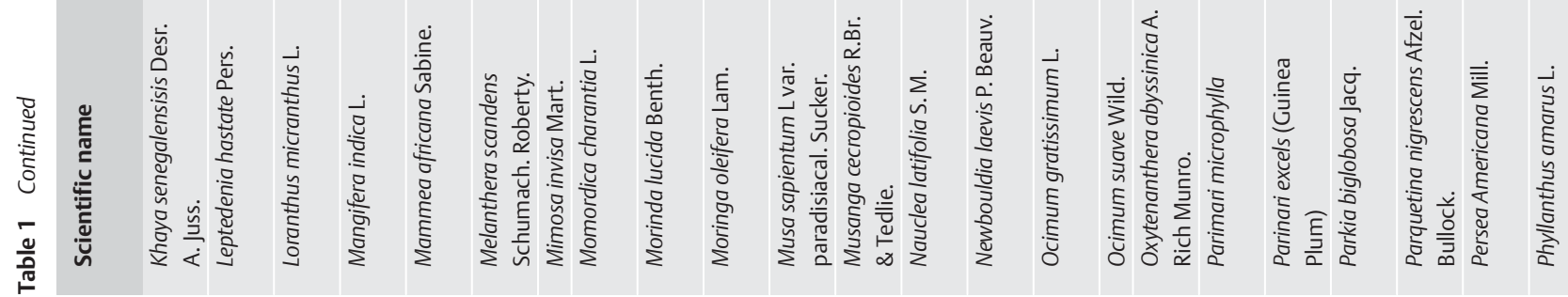




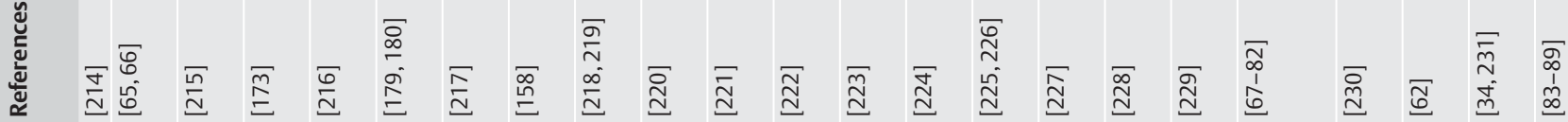

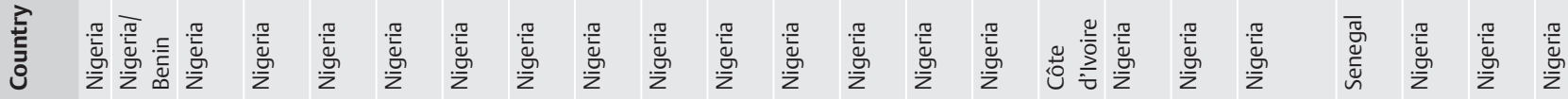

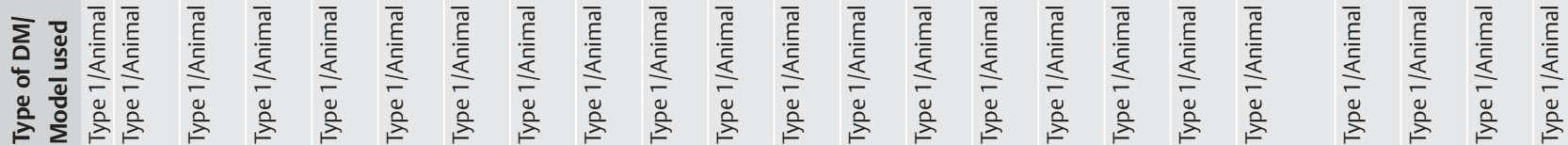

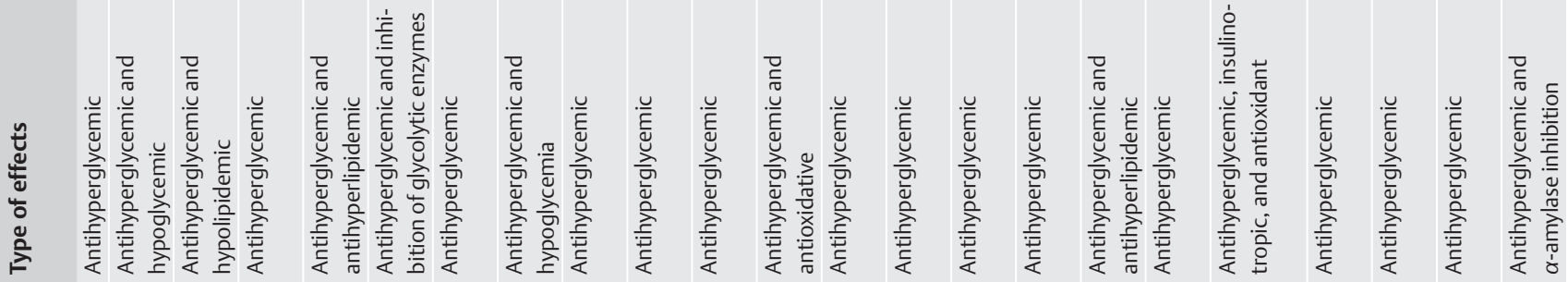

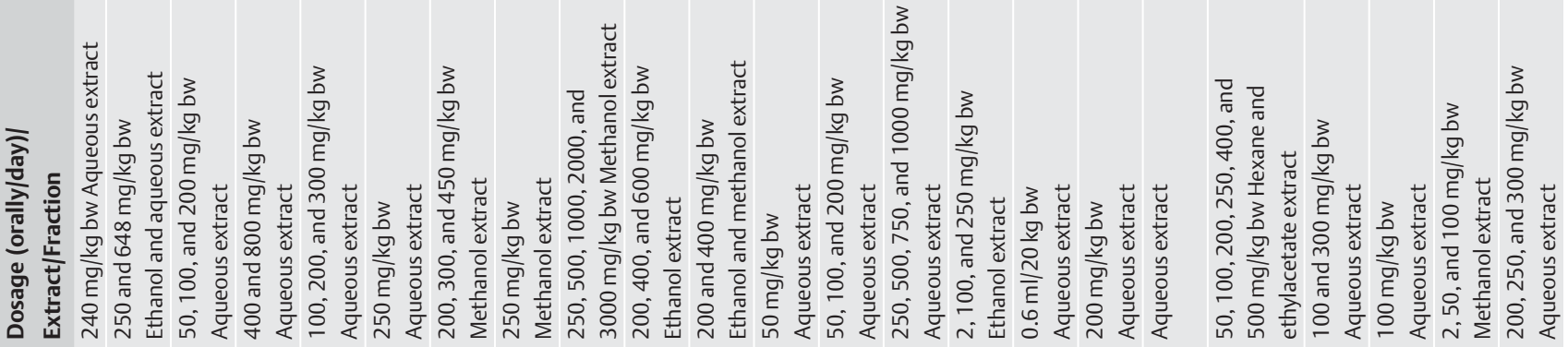

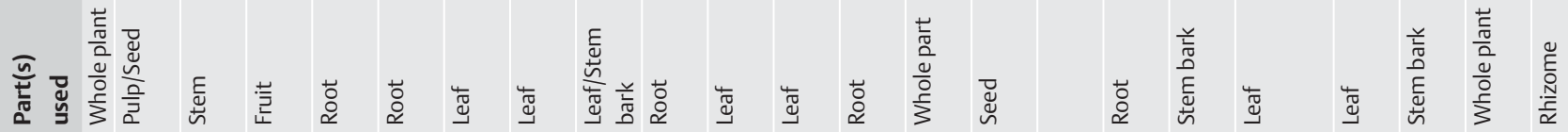

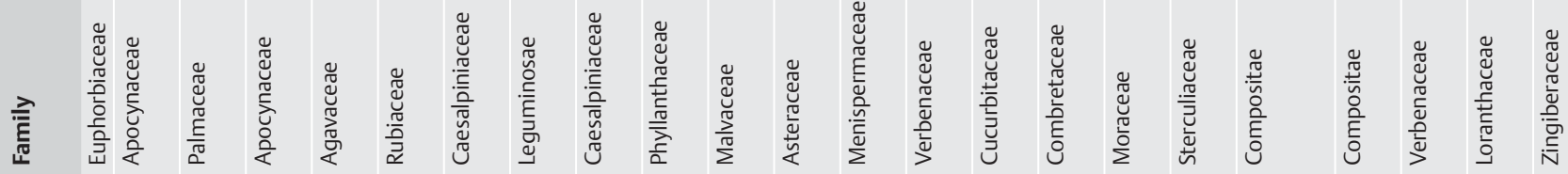

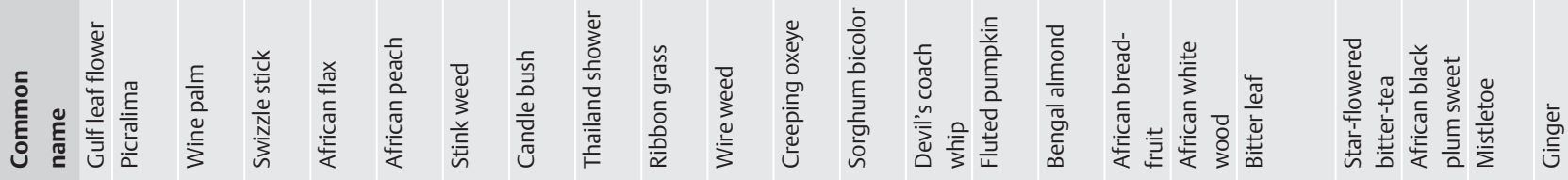

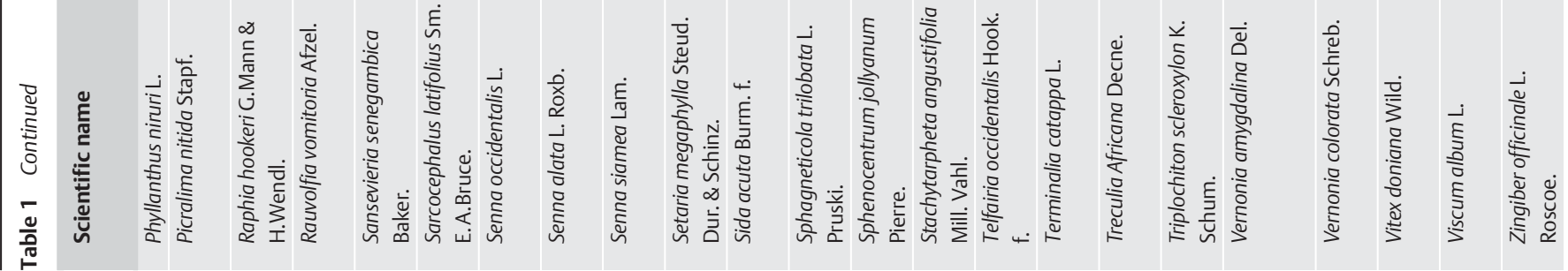


Table 2 List of scientifically investigated antidiabetic medicinal plants from East Africa.

\begin{tabular}{|c|c|c|c|c|c|c|c|c|}
\hline $\begin{array}{l}\text { Scientific } \\
\text { name }\end{array}$ & $\begin{array}{l}\text { Common } \\
\text { name }\end{array}$ & Family & $\begin{array}{l}\text { Part(s) } \\
\text { used }\end{array}$ & $\begin{array}{l}\text { Dosage (orally/day)/ } \\
\text { Extract/Fraction }\end{array}$ & Type of effects & $\begin{array}{l}\text { Type of DM/ } \\
\text { Model used }\end{array}$ & $\begin{array}{l}\text { Coun- } \\
\text { try }\end{array}$ & $\begin{array}{l}\text { Refer- } \\
\text { ence }\end{array}$ \\
\hline $\begin{array}{l}\text { Aspilia pluriseta } \\
\text { Schweinf. }\end{array}$ & Dwarf aspilia & Asteraceae & Root & $\begin{array}{l}50,100 \text {, and } 200 \mathrm{mg} / \mathrm{kg} \\
\text { bw Aqueous extract }\end{array}$ & $\begin{array}{l}\text { Antihyper- } \\
\text { glycemic }\end{array}$ & Type 1/Animal & Kenya & [232] \\
\hline Bidens pilosa L. & $\begin{array}{l}\text { Spanish } \\
\text { needle }\end{array}$ & Asteraceae & Leaf & $\begin{array}{l}50,100 \text {, and } 200 \mathrm{mg} / \mathrm{kg} \\
\text { bw Aqueous extract }\end{array}$ & $\begin{array}{l}\text { Antihyper- } \\
\text { glycemic }\end{array}$ & Type 1/Animal & Kenya & [232] \\
\hline $\begin{array}{l}\text { Caylusea abys- } \\
\text { sinica Fresen. } \\
\text { Fisch. \& Mey. }\end{array}$ & - & Resedaceae & Leaf & $\begin{array}{l}100,200 \text {, and } 300 \mathrm{mg} / \\
\mathrm{kg} \text { bw Methanol extract }\end{array}$ & $\begin{array}{l}\text { Antihyper- } \\
\text { glycemic }\end{array}$ & Type 1/Animal & $\begin{array}{l}\text { Ethio- } \\
\text { pia }\end{array}$ & [133] \\
\hline $\begin{array}{l}\text { Catha edulis } \\
\text { Vahl. }\end{array}$ & $\begin{array}{l}\text { Bushman's } \\
\text { tea }\end{array}$ & $\begin{array}{l}\text { Celastra- } \\
\text { ceae }\end{array}$ & Root & $\begin{array}{l}50,100 \text {, and } 200 \mathrm{mg} / \mathrm{kg} \\
\text { bw Aqueous extract }\end{array}$ & $\begin{array}{l}\text { Antihyper- } \\
\text { glycemic }\end{array}$ & Type 1/Animal & Kenya & [232] \\
\hline $\begin{array}{l}\text { Erythrina abys- } \\
\text { sinica Lam. }\end{array}$ & $\begin{array}{l}\text { Red-hot- } \\
\text { poker }\end{array}$ & Fabaceae & $\begin{array}{l}\text { Stem } \\
\text { bark }\end{array}$ & $\begin{array}{l}50,100 \text {, and } 200 \mathrm{mg} / \mathrm{kg} \\
\text { bw Aqueous extract }\end{array}$ & $\begin{array}{l}\text { Antihyper- } \\
\text { glycemic }\end{array}$ & Type 1/Animal & Kenya & [232] \\
\hline $\begin{array}{l}\text { Ficus sycomorus } \\
\text { L. }\end{array}$ & Fig-mulberry & Moraceae & $\begin{array}{l}\text { Stem } \\
\text { bark }\end{array}$ & $\begin{array}{l}50,100 \text {, and } 150 \mathrm{mg} / \mathrm{kg} \\
\text { bw Aqueous extract }\end{array}$ & $\begin{array}{l}\text { Antihyper- } \\
\text { glycemic }\end{array}$ & Type 1/Animal & Kenya & [233] \\
\hline $\begin{array}{l}\text { Moringa steno- } \\
\text { petala Baker f. }\end{array}$ & Cabbage tree & $\begin{array}{l}\text { Moringa- } \\
\text { ceae }\end{array}$ & Leaf & $\begin{array}{l}500 \mathrm{mg} / \mathrm{kg} \mathrm{bw} \\
\text { Butanol fraction }\end{array}$ & $\begin{array}{l}\text { Antihyper- } \\
\text { glycemic and } \\
\text { hypoglycemic }\end{array}$ & Type 1/Animal & $\begin{array}{l}\text { Ethio- } \\
\text { pia }\end{array}$ & [137] \\
\hline $\begin{array}{l}\text { Pappea capensis } \\
\text { Eckl. \& Zeyh. }\end{array}$ & Jacket plum & $\begin{array}{l}\text { Sapinda- } \\
\text { ceae }\end{array}$ & $\begin{array}{l}\text { Leaf/ } \\
\text { Stem } \\
\text { bark }\end{array}$ & $\begin{array}{l}100 \text { and } 200 \mathrm{mg} / \mathrm{kg} \text { bw } \\
\text { Aqueous and ethylace- } \\
\text { tate extract }\end{array}$ & $\begin{array}{l}\text { Antihyper- } \\
\text { glycemic }\end{array}$ & Type 1/Animal & Kenya & [234] \\
\hline $\begin{array}{l}\text { Pentas schim- } \\
\text { periana A. Rich. }\end{array}$ & - & Rubiaceae & Leaf & $\begin{array}{l}500 \text { and } 1000 \mathrm{mg} / \mathrm{kg} \text { bw } \\
\text { Aqueous extract }\end{array}$ & $\begin{array}{l}\text { Antihyper- } \\
\text { glycemic }\end{array}$ & Type 1/Animal & $\begin{array}{l}\text { Ethio- } \\
\text { pia }\end{array}$ & [235] \\
\hline $\begin{array}{l}\text { Strychnos hen- } \\
\text { ningsii Gilg. }\end{array}$ & $\begin{array}{l}\text { Red bitter } \\
\text { berry }\end{array}$ & Loganiaceae & Leaf & $\begin{array}{l}50,100 \text {, and } 200 \mathrm{mg} / \mathrm{kg} \\
\text { bw Aqueous extract }\end{array}$ & $\begin{array}{l}\text { Antihyper- } \\
\text { glycemic }\end{array}$ & Type 1/Animal & Kenya & [232] \\
\hline
\end{tabular}

West Africa where citations were used as a criteria in addition to the potency of the results.

\section{West Africa}

Anacardium occidentale L. (Anacardiaceae), or cashew, is perhaps one of the most cited plants from West Africa. The antidiabetic activity of a stem-bark methanol extract was investigated in a fructose-fed type 2 diabetes (T2D) model of rats [22]. Treatment with $200 \mathrm{mg} / \mathrm{kg}$ body weight (bw)/day of the extract given orally significantly ameliorated the changes in plasma glucose, lipid profile, malonyldialdehyde, urea, and creatinine induced by an enriched fructose diet, but showed no effect on plasma alkaline phosphatase levels. Extract treatment reduced plasma glucose levels by almost $40 \%$ in fructose-fed type 2 diabetic rats. In another study, oral administration of an ethanolic extract of inner bark and fractions at various doses administered caused a significant decrease in blood glucose levels in a type 1 diabetes (T1D) model of rats [23]. The crude extract decreased blood glucose by $36.8 \%$ at $700 \mathrm{mg} / \mathrm{kg}$ bw when different fractions at 300,30, and $200 \mathrm{mg} /$ $\mathrm{kg}$ bw/day indicated a glycemic decrease of $18.4 \%, 15.6 \%$, and $17.3 \%$, respectively. Furthermore, bioactivity-guided fractionation of the ethanolic extract led to fractions that displayed diverse polyphenolic compounds, which are known for their hypoglycemic effect. The methanolic leaf extract, orally administered at $400 \mathrm{mg} / \mathrm{kg}$ bw/day, decreased the blood glucose levels of alloxanized rats by $20.8 \%$ after 4 hours of treatment compared to $47.63 \%$ for tolbutamide, a standard antidiabetic drug [24]. More recently, Ukwenya et al. [25] reported that administration of a methanolic leaf extract at a dose of $300 \mathrm{mg} / \mathrm{kg}$ bw recovered the beta cell damage in a T1D model of rats. Although an extensive antidiabetic study on this plant is yet to be done, the preliminary data indicates that the stem bark contains more therapeutically active antidiabetic phytochemicals than the other parts of the plant.
Another highly cited antidiabetic plant is Azadirachta indica A. Juss. (Meliaceae), which is commonly referred to as neem tree. The hypoglycemic and antihyperglycemic effects of the leaves in a T1D model of rats have been investigated [26,27]. Oral treatment of the aqueous extract at $400 \mathrm{mg} / \mathrm{kg}$ bw/day was found to decrease fasting blood glucose by $54 \%$ compared to the control. Further studies were conducted by Akinlola et al. [28], who reported that the ethanolic extract orally administered at $500 \mathrm{mg} /$ $\mathrm{kg}$ bw/day prevented intestinal lesions and decreased hyperglycemia (87.5\%) in an STZ-induced T1D model of rats. Moreover, in 2010, Akinlola et al. [29] evaluated the chronic treatment of diabetic rats with an $A$. indica leaf ethanolic extract at $500 \mathrm{mg} / \mathrm{kg}$ bw/day orally on blood glucose, pancreatic islet histopathology, and oxidative status of the pancreas. The results obtained were quite promising, the fasting blood glucose of the extract-treated group dropped to $50 \%$, the number of $\beta$-cells was improved and, similarly, islet histology showed a marked improvement with a significant decrease in oxidative stress. In 2011, this research group also indicated that the oral administration of $A$. indica leaf extract at $500 \mathrm{mg} / \mathrm{kg}$ bw/day ameliorated the renal damage in an STZ-induced T1D model of rats [30]. In another study, an orally administered ethanolic leaf extract at $400 \mathrm{mg} / \mathrm{kg}$ bw/day was reported to decrease fasting blood glucose by $50 \%$ and further prevented the alterations posed by DM on immunological and hematological parameters [31] which have clinical significance in the control of atherosclerosis and other diabetes-associated vascular complications.

Gongronema latifolium Benth. (Asclepiadaceae) is another plant that received much attention as a hypoglycemic and antihyperglycemic agent in Africa. Almost all of its parts are claimed to have an antidiabetic effect. Treatment with the aqueous leaf extract at various dosages was found to decrease the fasting blood glucose in an STZ-induced T1D model of rats [32-35]. Fasting blood glucose dropped by $30.4 \%$ compared to untreated diabetic animals. Akah et al. [36] reported that treatment with both aque- 


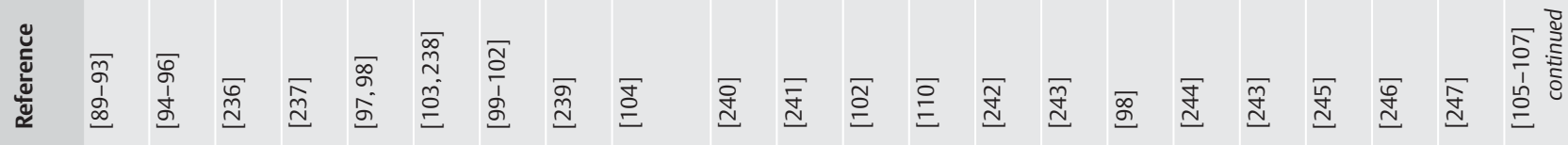

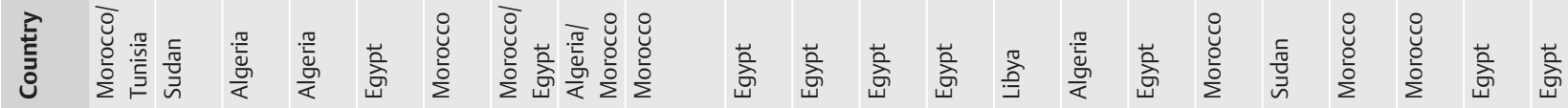

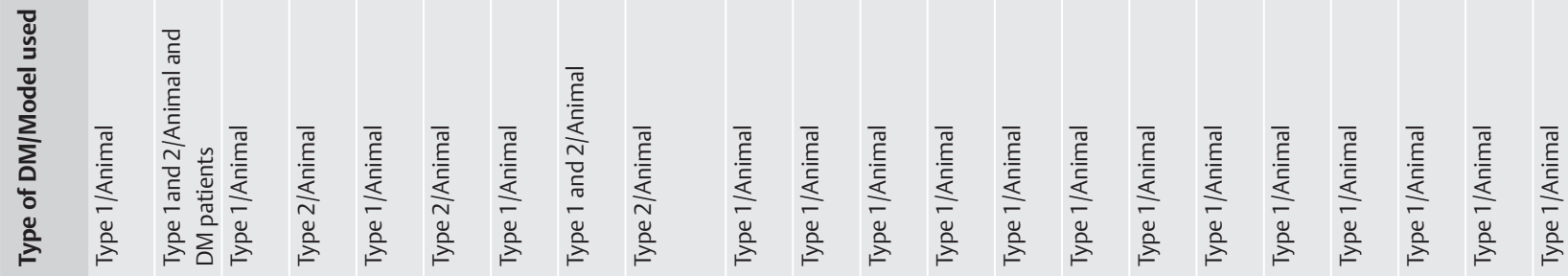

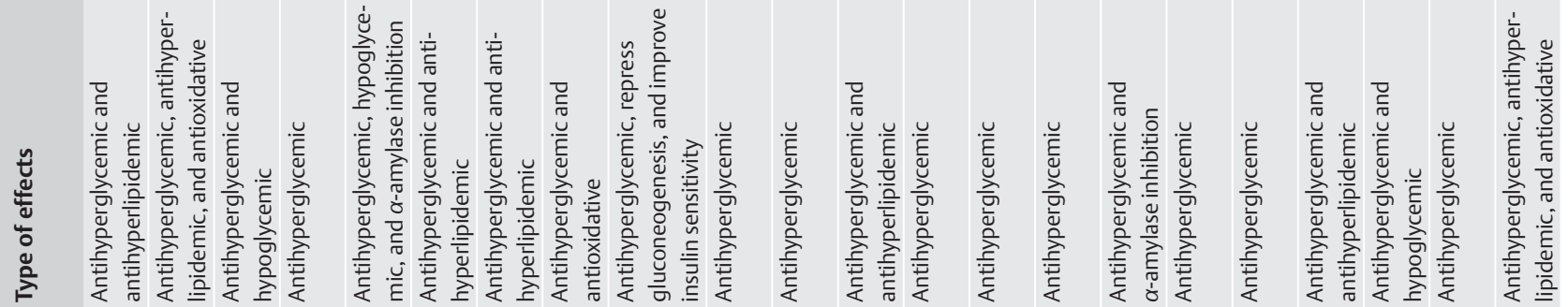

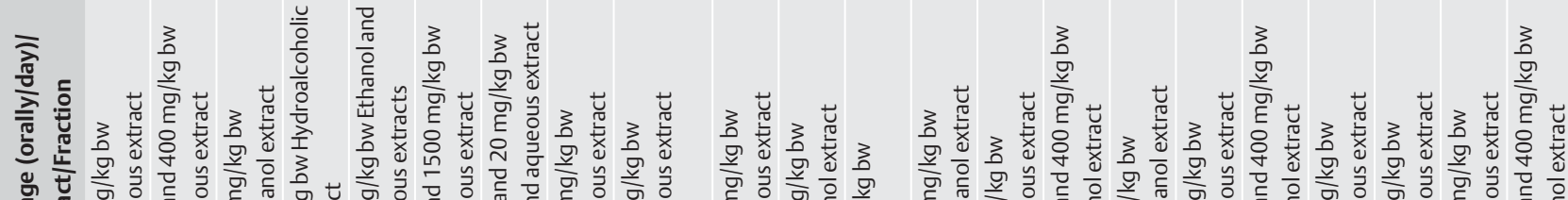
Whan

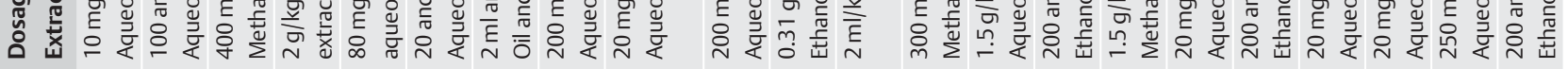

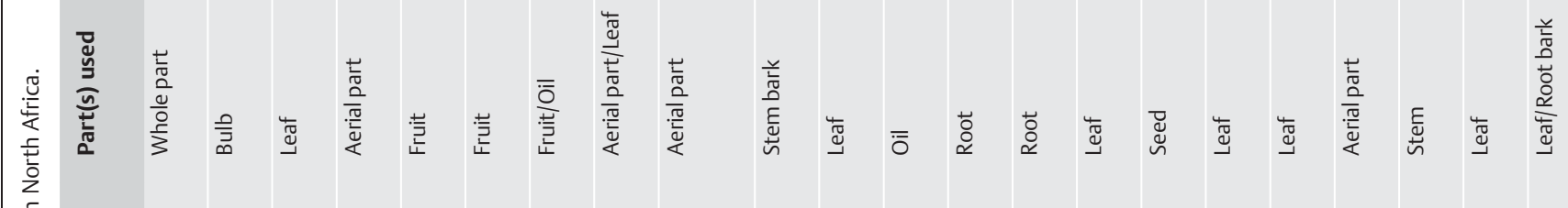
1)

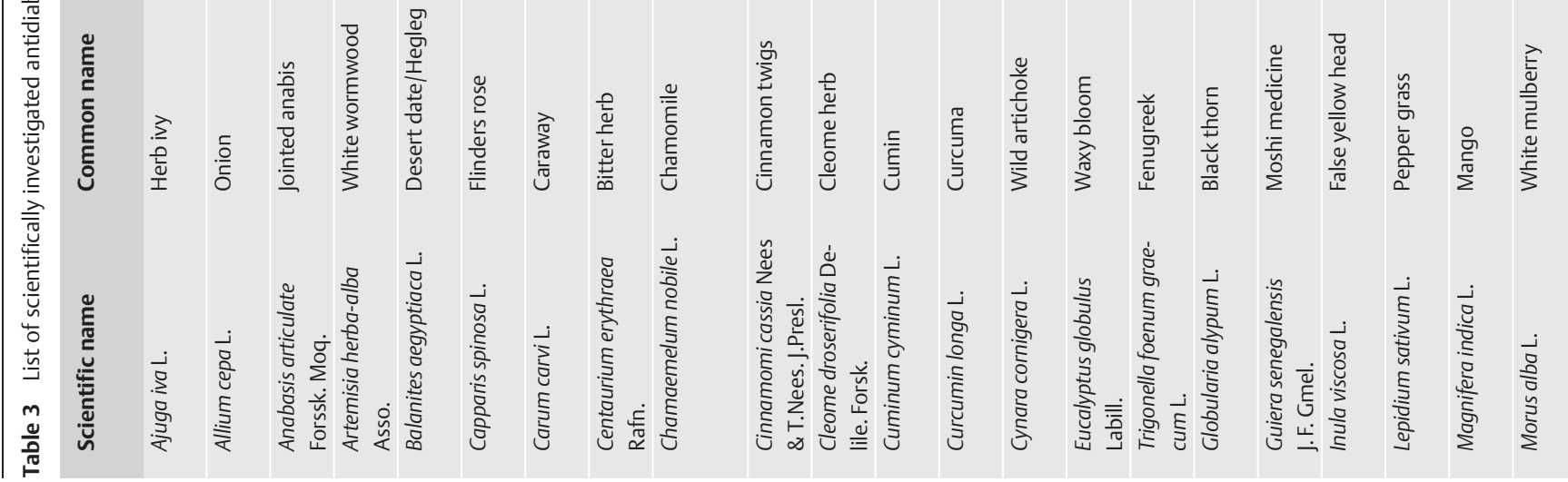




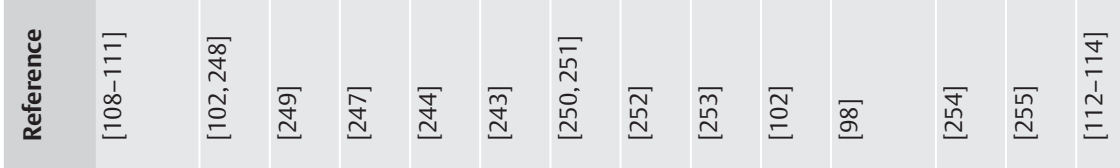

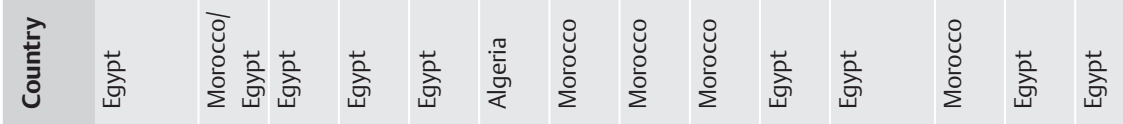

$\prod 11111111111$

IIIIIIUWmWm

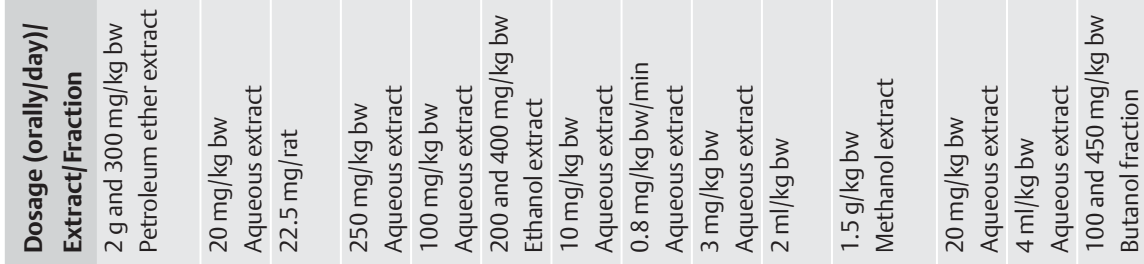

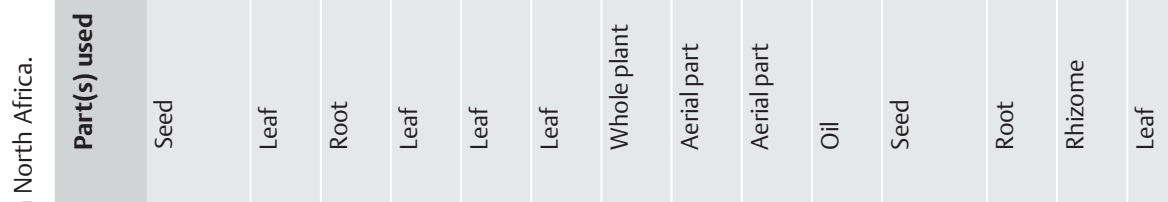

1\|\|\|\|\|\|\|\|

离

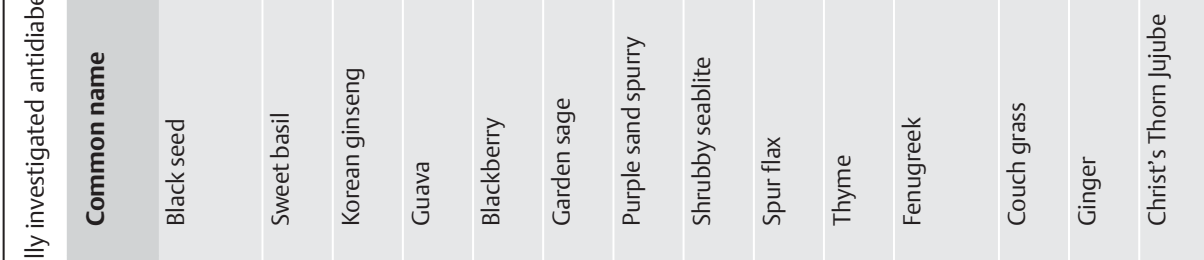

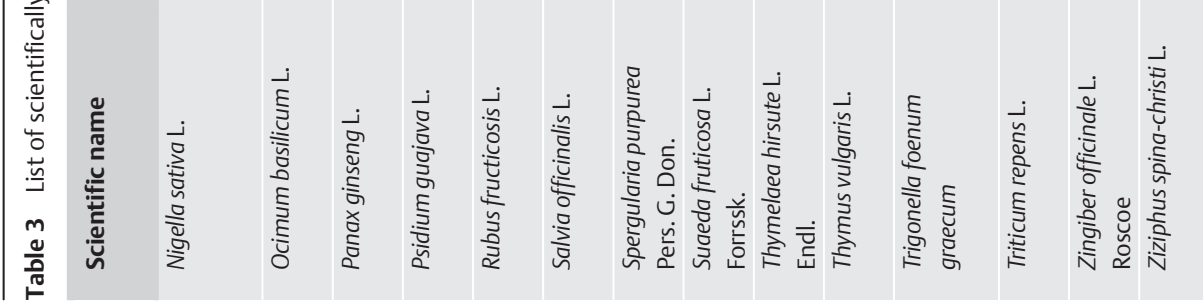




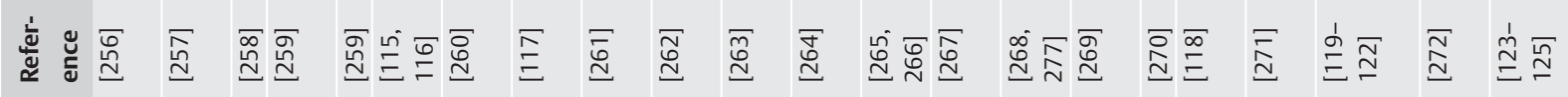

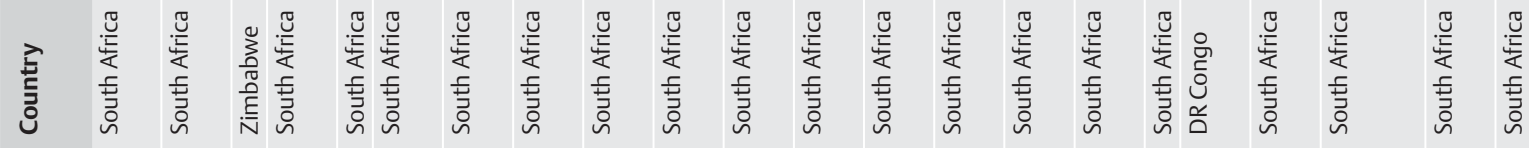

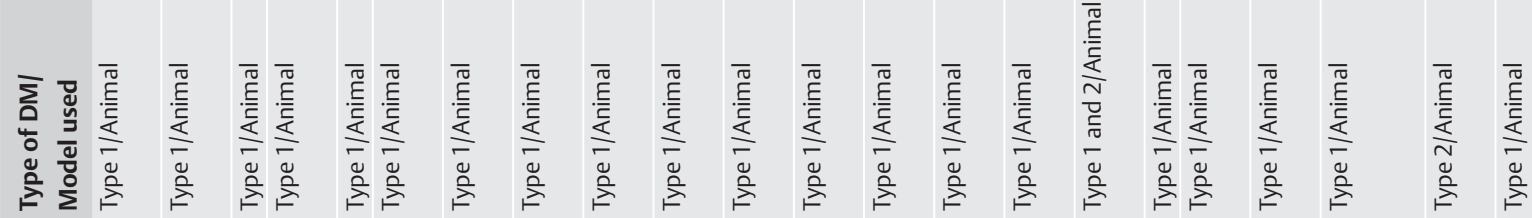

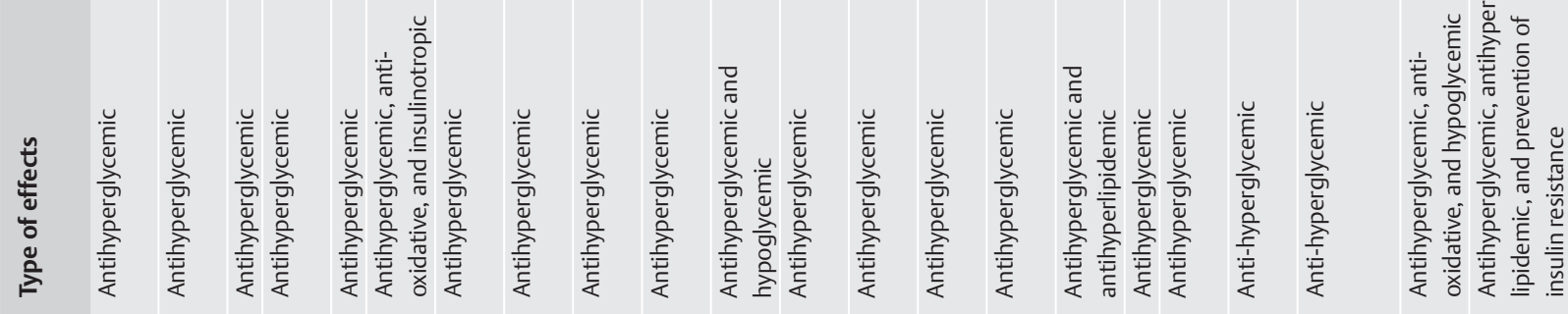

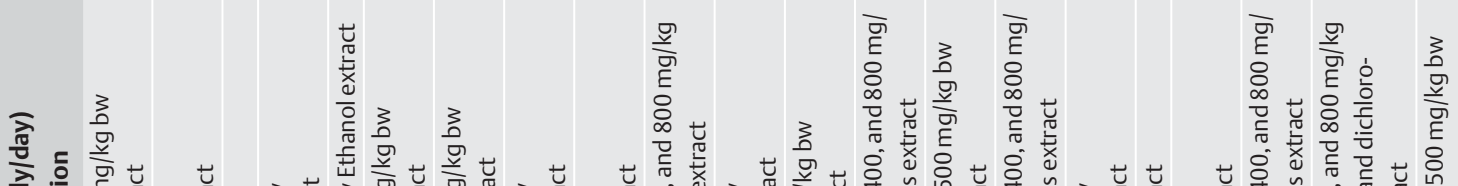

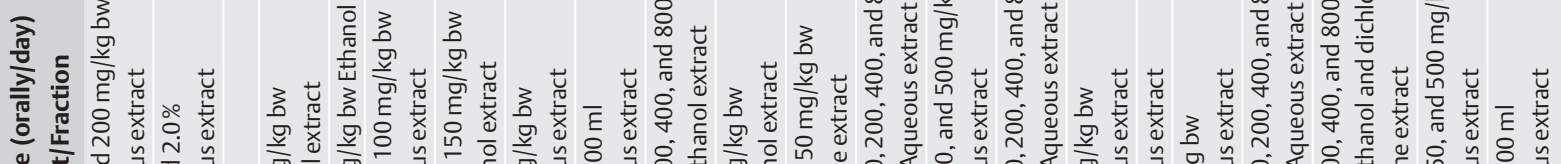

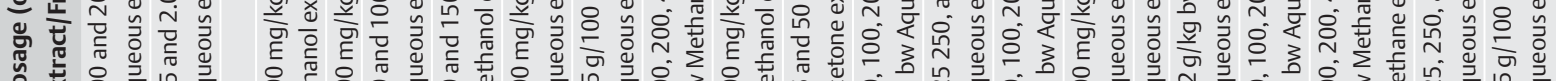

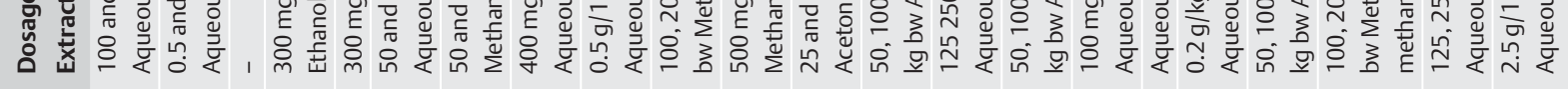

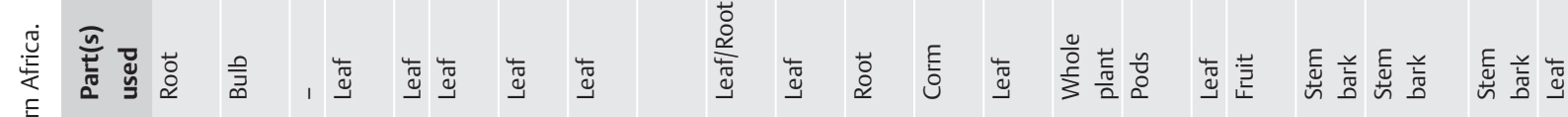

1\|\|\|\|\|\|\|\|\|\|$\| \amalg$

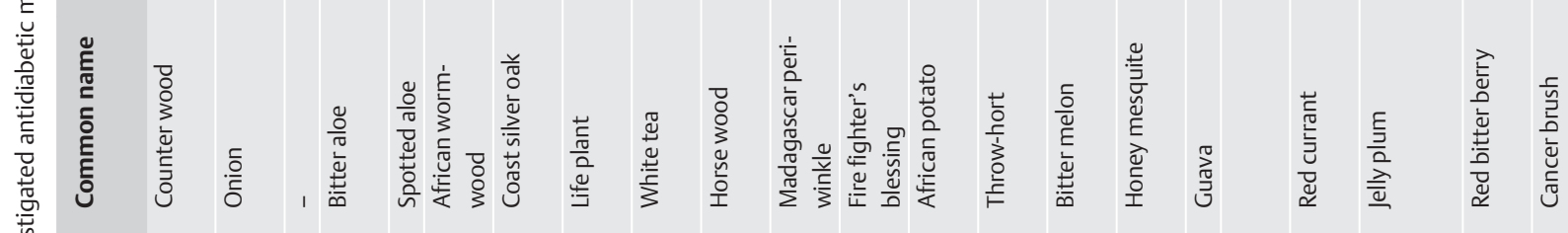

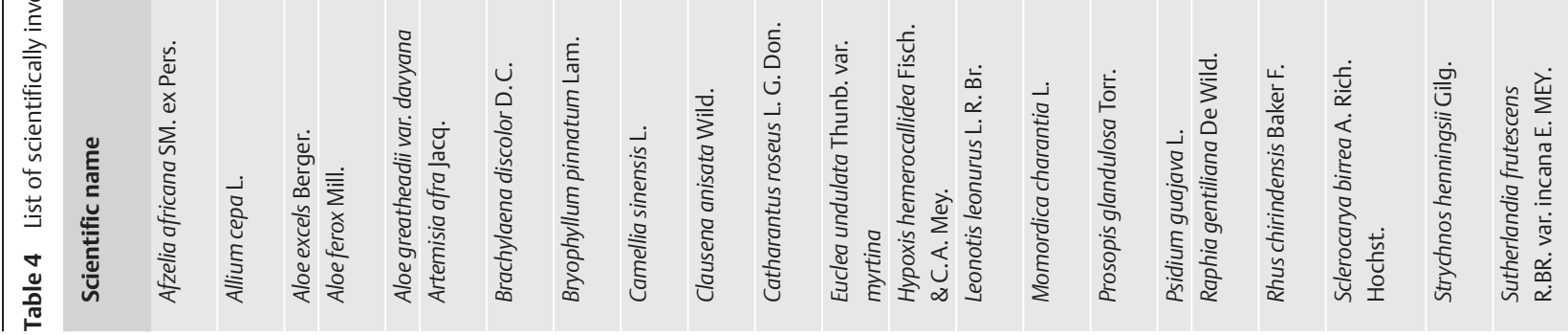




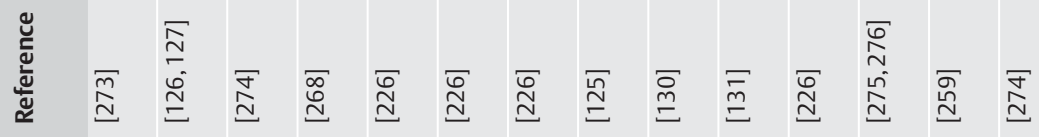

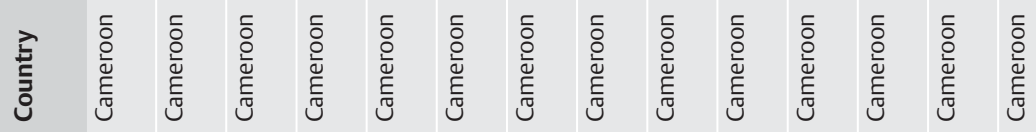

111111111111

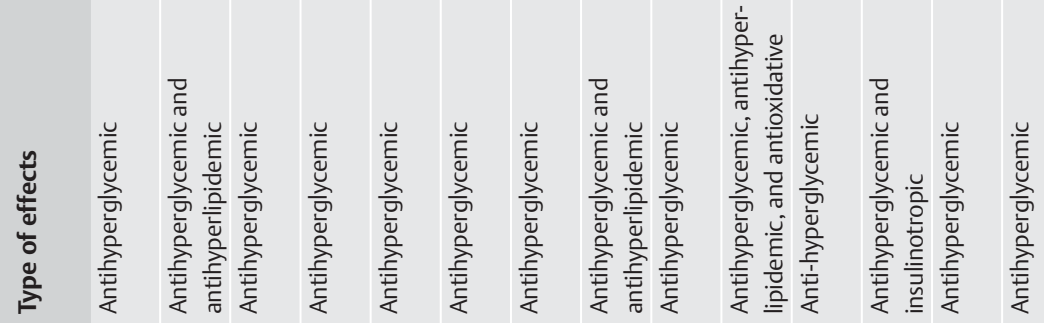

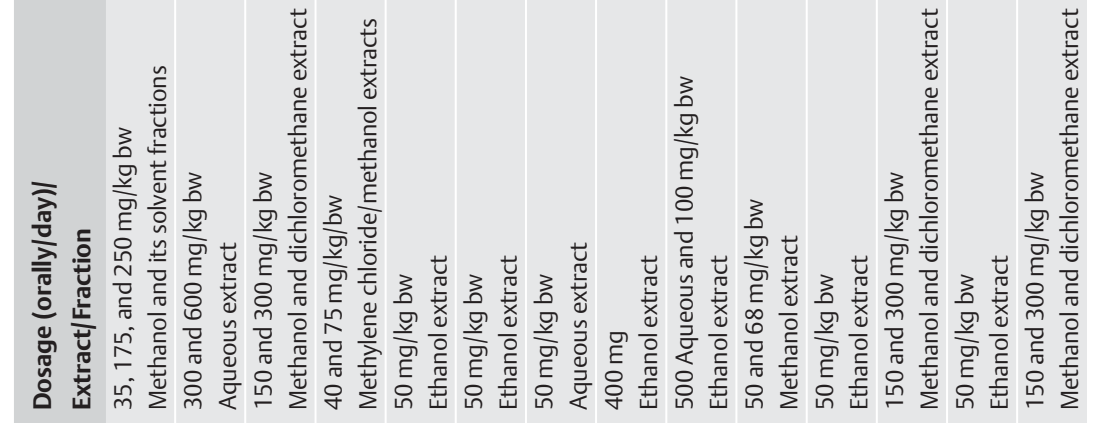

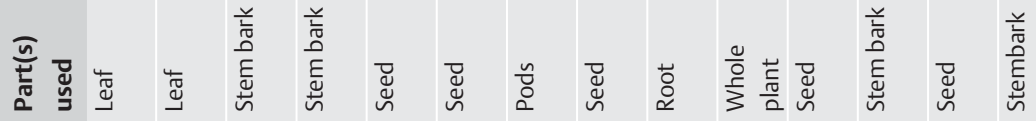

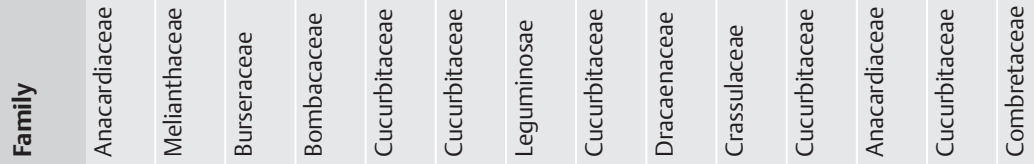

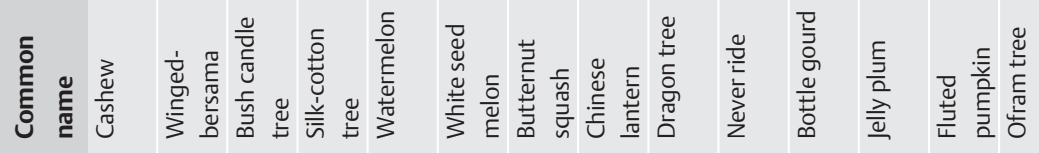

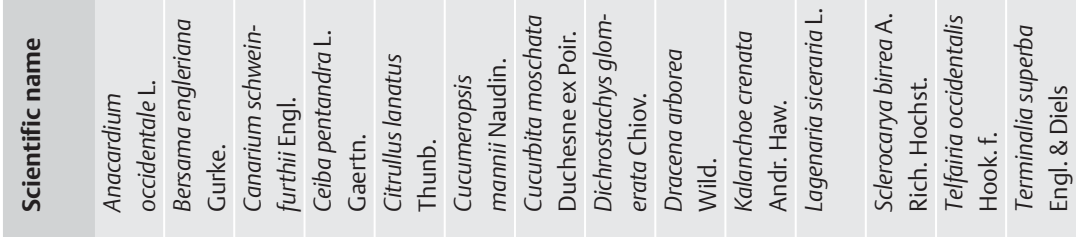



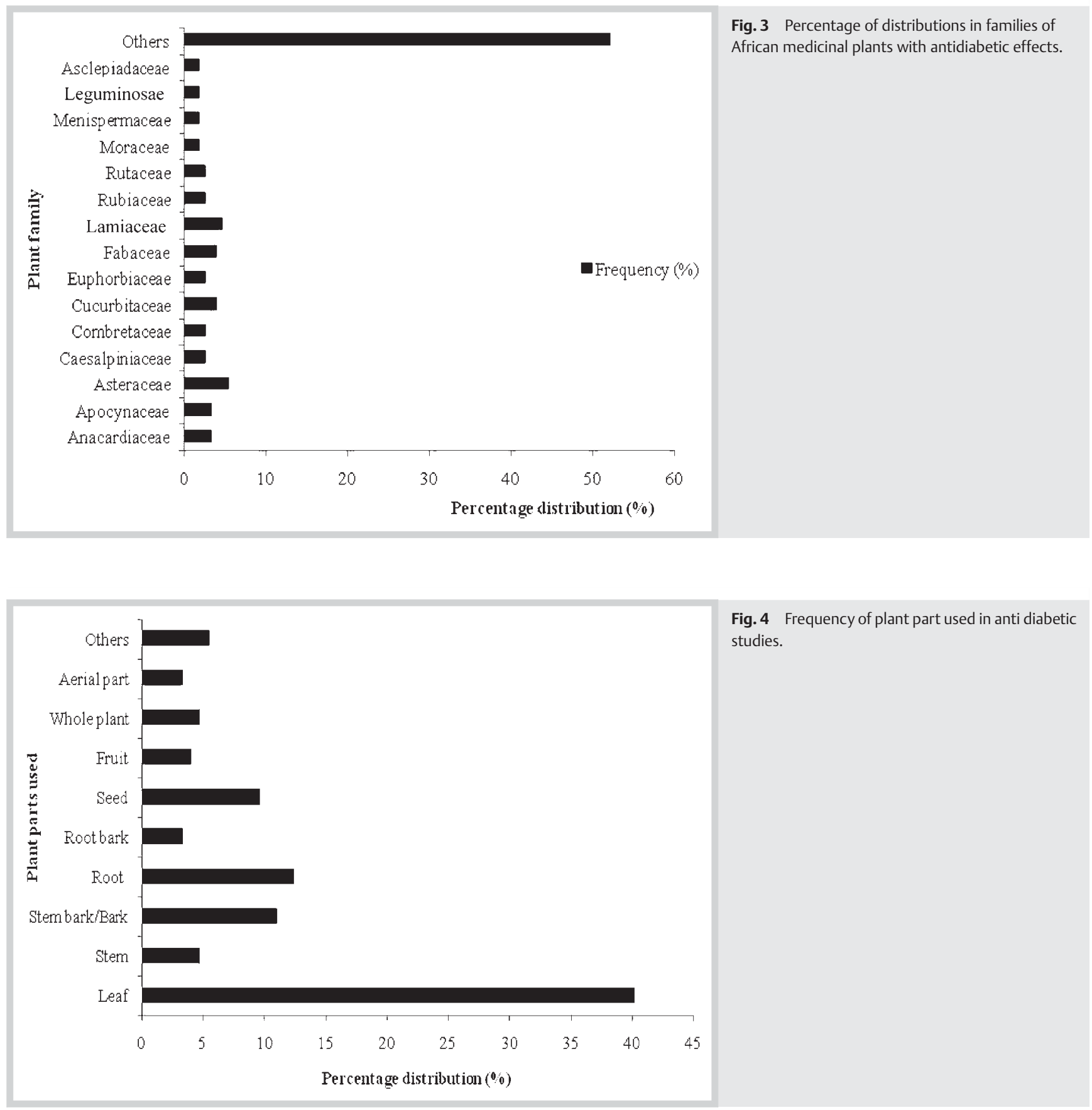

ous and methanolic extracts and fractions at $800 \mathrm{mg} / \mathrm{kg}$ bw showed a significant antihyperglycemic effect in an experimentally-induced T1D model of rats. The highest glycemic reduction recorded was $43 \%$ at $32 \mathrm{~h}$ post-treatment of the crude aqueous extract compared to $35 \%$ for the methanolic extract. The methanolic fraction showed the highest decrease in glycemia (30\%) at $400 \mathrm{mg} / \mathrm{kg}$ bw after 32 hours of treatment. Furthermore, these extracts showed a protective effect on the activity of some cardiac enzymes, which are crucial in the management of DM, in the same model of diabetic rats [37]. In an attempt to investigate the possible mechanism of action, Adebajo et al. [38] reported the insulinotropic and glucose lowering effects of the combined root and stem bark methanolic extracts $(1: 1)$ and various fractions when administered orally at a dose of $100 \mathrm{mg} / \mathrm{kg}$ bw/day. It was observed that the effect of the combined extracts was far better than the individual actions of the fractions. Both the extract and fractions caused an insulin release and lowered the blood glucose levels better than glibenclimide in glucose-loaded rats and INS-1 cell lines. In another study, oral administration of ethanolic roots and twig extracts at 200 and $400 \mathrm{mg} / \mathrm{kg} \mathrm{bw} /$ day showed a protective effect against alterations on the markers of kidney functions in a T1D model of rats [39]. Fasting blood glucose dropped by more than $60 \%$ for a single twig administered via orogastric intubation compared to $43 \%$ for the root ethanolic extracts.

The hypoglycemic and hypolipidemic effects of Hibiscus sabdarif$f a$ L. (Malaceae) calyces have been reported [40]. The authors showed that the oral administration of the aqueous extract at $0.5 \mathrm{mg} / \mathrm{ml} /$ day alleviated the oxidative stress in a T1D model of rats [41], which is comparable to vitamin $C$ and glibenclimide. The extract decreased fasting blood glucose by almost $70 \%$, 
Table 6 Scientifically investigated African antidiabetic medicinal plants with identified possible bioactive compounds.

\begin{tabular}{|c|c|c|c|c|c|c|}
\hline $\begin{array}{l}\text { Scientific } \\
\text { name }\end{array}$ & $\begin{array}{l}\text { Common } \\
\text { name }\end{array}$ & Family & Part(s) used & $\begin{array}{l}\text { Possible compound(s) } \\
\text { present/isolated }\end{array}$ & Country & Reference \\
\hline $\begin{array}{l}\text { Anacardium } \\
\text { occidentale }\end{array}$ & Cashew & Anacardiaceae & $\begin{array}{l}\text { Leaf/n-hexane/ } \\
\text { diethylether fractions }\end{array}$ & $\begin{array}{l}\text { Polyphenols, terpenoids, alkaloids, and } \\
\text { flavonoids }\end{array}$ & Nigeria & [23] \\
\hline $\begin{array}{l}\text { Balanites } \\
\text { aegyptiaca }\end{array}$ & $\begin{array}{l}\text { Desert date/ } \\
\text { Hegleg }\end{array}$ & Balanitaceae & $\begin{array}{l}\text { Fruit/chloroform:me- } \\
\text { thanol:water }\end{array}$ & Diosgenin & Egypt & {$[97,98]$} \\
\hline Carum carvi & Caraway & Apiaceae & Fruit oil & $\begin{array}{l}\text { D-limonene, benzyl alcohol, O-cresol, } \\
\text { isomenthone, methyl chavicol, D-car- } \\
\text { vone, perillaldehyde, and } \beta \text {-patchoullene }\end{array}$ & $\begin{array}{l}\text { Morocco/ } \\
\text { Egypt }\end{array}$ & [99-102] \\
\hline $\begin{array}{l}\text { Gongronema } \\
\text { latifolium }\end{array}$ & $\begin{array}{l}\text { Amaranth } \\
\text { globe }\end{array}$ & $\begin{array}{l}\text { Asclepiada- } \\
\text { ceae }\end{array}$ & $\begin{array}{l}\text { Root stem/methanol } \\
\text { extract }\end{array}$ & $\begin{array}{l}\alpha \text { and } \beta \text {-amyrin cinnamates, lupenyl cin- } \\
\text { namates, lupenyl acetate, and two other } \\
\text { unknown triterpenoids } Y \text { and } Z\end{array}$ & Nigeria & [38] \\
\hline Morus alba & $\begin{array}{l}\text { White } \\
\text { mulberry }\end{array}$ & Moraceae & $\begin{array}{l}\text { Root bark/water- } \\
\text { methanol fractions }\end{array}$ & 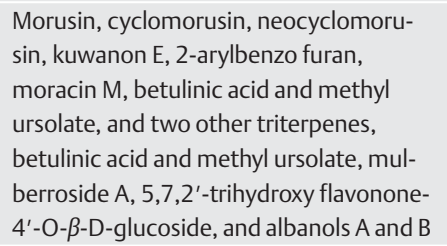 & Egypt & [105-107] \\
\hline $\begin{array}{l}\text { Trigonella foe- } \\
\text { num graecum }\end{array}$ & Fenugreek & Leguminosae & $\begin{array}{l}\text { Seed/chloroform: me- } \\
\text { thanol: water fractions }\end{array}$ & Diosgenin & Egypt & [98] \\
\hline $\begin{array}{l}\text { Ziziphus } \\
\text { spina-christi }\end{array}$ & $\begin{array}{l}\text { Christ's Thorn } \\
\text { Jujube }\end{array}$ & Rhamnaceae & Leaf/butanol fraction & Chritinin-A & Egypt & [112-114] \\
\hline
\end{tabular}

which is comparable to ascorbic acid and glibenclimide. To investigate the possible mode of action, Adedayo and Ganiyu [42] revealed that the extract inhibited the activities of the two key enzymes involved in carbohydrate digestion, alpha glucosidase and alpha amylase, which are very crucial in the management of T2D mellitus.

Using an alloxan-induced T1D rat model, Tanko et al. [43,44] demonstrated the glucose lowering effect of the hydromethanolic extract of the Indigofera pulchra L. (Papilionaceae) leaf when administered orally at 250,500 , and $1000 \mathrm{mg} / \mathrm{kg}$ bw/day. Surprisingly, the lower dosage that was administered decreased the glucose levels by $50 \%$ after 8 hours post-treatment. The daily intraperitoneal administration of ethyl acetate and $n$-butanol fractions of this extract also showed a hypoglycemic effect [45, 46 ] and was able to restore the DM-induced hematological alterations.

Nauclea latifolia S. M. (Rubiaceae) is among the most widely used traditional plants in the management of DM in the different parts of Nigeria. In an attempt to investigate this claim by traditional herbalists, Gidado et al. [47] showed that the oral treatment of the aqueous leaf extract of $N$. latifolia at $200 \mathrm{mg} / \mathrm{kg}$ bw/day significantly decreased blood glucose levels in a T1D model of rats, which was $45 \%$ within a 4 -hour period of treatment. Further studies by this group indicated that both the aqueous and ethanolic leaf extracts at 100, 200, and $400 \mathrm{mg} / \mathrm{kg}$ bw/day significantly decreased the blood glucose levels in a dose-dependent manner when administered orally. At $400 \mathrm{mg} / \mathrm{kg}$ bw, aqueous and ethanolic leaf extracts lowered fasting blood glucose by $31.7 \%$ and $36.1 \%$, respectively, [48] and were able to inhibit maltase and sucrase activities in vitro but not in vivo [49]. Other researchers reported that stem and root ethanolic extracts administered intraperitoneally at $25 \mathrm{mg} / \mathrm{kg}$ bw/day have potent immunosuppressive effects on $\mathrm{T}$ cell proliferation in an STZ-induced T1D model of rats [50] and could improve the antioxidant status and hormonal changes in another diabetes rat model [51].
Ocimum gratissimum L. (Lamiaceae) is used widely as a condiment or spice in different cultural settings in Africa. It is traditionally used for the management of DM [52]. Intraperitoneal administration of $400 \mathrm{mg} / \mathrm{kg}$ bw/day of 0 . gratissimum methanolic leaf extract significantly decreased the blood glucose level in both normal and T1D models of rats by $56 \%$ and $69 \%$, respectively [ 53 , 54]. Oral treatments at 500,1000, and $1500 \mathrm{mg} / \mathrm{kg}$ bw/day of the aqueous leaf extract dropped the fasting blood glucose by more than 50\% [55]. Mohammed et al. [56] also showed that the administration of $500 \mathrm{mg} / \mathrm{kg}$ bw of this extract caused a reduction in blood glucose by $81.3 \% 24$ hours after administration. Moreover, the 0 . gratissimum leaf ethanolic extract treated at $200 \mathrm{mg} /$ $\mathrm{kg}$ bw/day prevented the alteration of germinal epithelium, distortion of seminiferous tubules, as well as vacuolation of seminiferous tubules in an STZ-induced T1D model of rats [57,58]. More recently, Oguanobi et al. [59] reported that oral administration of the 0 . gratissimum leaf extract at 100,200 , and $300 \mathrm{mg} / \mathrm{kg}$ bw/ day had a blood glucose lowering effect and the ability to alleviate derangements in serum and biliary bilirubin, cholesterol, and electrolytes in a neonatal STZ-induced T2D rat model [60].

Phyllanthus amarus L. (Euphorbiaceae) (stone breaker or gulf flower) is another highly cited antidiabetic plant from West Africa. The hypoglycemic potential of the aqueous leaf extract of $P$. amarus was investigated in an alloxan-induced T1D rat model. The extract at a dose of $260 \mathrm{mg} / \mathrm{kg}$ bw produced a significant $(\mathrm{p}<0.05)$ reduction in blood glucose level by $112 \%, 61 \%$, and $31 \%$ at 24 hours, 7 days, and 14 days of oral administration, respectively. Furthermore, the reduction was dose-dependent and dropped by $82 \%, 41 \%$, and $16 \%$ after 24 hours, 7 days, and 14 days of oral administration, respectively [61]. Owolabi et al. [62] reported that oral treatment of the aqueous extract at $100 \mathrm{mg} / \mathrm{kg}$ bw/day decreased fasting blood glucose by $46.53 \%$ compared to $66.6 \%$ for insulin treatment in a T1D model of rats. In another study from Togo, Povi et al. [63] indicated that P. amarus whole plant aqueous and hydroalcoholic extracts at 500 and $1000 \mathrm{mg} /$ $\mathrm{kg}$ bw/day had both hypoglycemic and hypolipidemic effects 
after 15 days of oral administration. Aqueous leaf and seed extracts at 150,300 , and $600 \mathrm{mg} / \mathrm{kg}$ bw/day were also shown to have antihyperglycemic, antihyperlipidemic, and cardioprotective effects as well as an insulin sensitizing effect in a T2D model of rats [64].

The hypoglycemic effect of the seed aqueous extract of Picralima nitida Stapf. (Apocynaceae) has been investigated in a T1D model of rats [65]. The extract at $648 \mathrm{mg} / \mathrm{kg}$ bw decreased the fasting blood glucose by about $19.46 \%$ and $75.5 \%$ in normoglycemic and alloxanized rats within 3 and 6 hours, respectively. However, a contradictory finding was reported by Igboasoiyi et al. [66] where the seed $(250 \mathrm{mg} / \mathrm{kg}$ bw/day), but not fruit pulp, extract showed no hypoglycemic effect.

The folkloric use of Vernonia amygdalina Del. (Compositae) (bitter leaf) in the management of DM is widely documented and this corroborates with the propensity of antidiabetic studies conducted in both type 1 and type 2 animal models of diabetes [6774] and human subjects [75]. In all studies reported, V. amygdalina was found to significantly reduce the hyperglycemia in T1D models of rats. The alterations on the markers of kidney functions were prevented by the leaf ethanolic extract administered at $400 \mathrm{mg} / \mathrm{kg}$ bw/day by gastric intubation and the fasting blood glucose was decreased by more than $80 \%$ [76]. Oral administration of this extract was also reported to prevent the macrovascular complications associated with DM [77]. In an attempt to further investigate the hypoglycemic effect of this plant, Akah et al. [78] reported that the hexane/ethyl acetate fraction obtained from the leaf methanolic extract possessed an antidiabetic effect when treated orally at 80,160 , and $320 \mathrm{mg} / \mathrm{kg}$ bw/day. The histological and hematological results showed no alterations on the full tissue architecture and other parameters analyzed. It was also reported that $V$. amygdalina leaf ethanolic extract at $100 \mathrm{mg} /$ $\mathrm{kg}$ bw/day prevented the alteration of germinal epithelium, distortion of seminiferous tubules, as well as vacuolation of seminiferous tubules in an STZ-induced T1D model of rats [58]. The synergistic or antagonistic effects of this plant with other traditionally claimed antidiabetic plants have also been documented in numerous studies [79-82].

Another plant that has received much attention from researchers and has been used in the management of DM is Zingiber officinale L. (Zingiberaceae) (ginger). Its hypoglycemic effect has been reported in STZ and glucose-induced diabetic rat models [83-85]. The glucose-lowering effect began after 30 minutes of intraperitoneal administration of a rhizome aqueous extract at 2, 4, and $8 \mathrm{mg} / \mathrm{kg}$ bw. At 200, 250, and $300 \mathrm{mg} / \mathrm{kg}$ bw, the decreases in the blood glucose levels were recorded as 51.4\%, 56.9\%, and $56.7 \%$, respectively. In another study, Iranloye et al. [86] investigated the antihyperglycemic and antioxidant effects of an orally administered aqueous extract of $Z$. officinale at $500 \mathrm{mg} / \mathrm{kg}$ bw/day in both type 1 and fructose-fed T2D models of rats. The extracts decreased blood glucose by $48.23 \%$ in type 1 , and $83.5 \%$ in T2D models of rats. The extract also showed the high radical scavenging ability and improvement of insulin biosynthesis in this experiment. It has also been reported that $Z$. officinale at doses of 250 and $500 \mathrm{mg} / \mathrm{kg}$ bw/day could inhibit oxidative stress and inflammation by enhancing antioxidant enzymes and TNF- $\alpha$ activity in an STZ-induced T1D model of rats [87]. Arikawe et al. [88], in their studies, indicated that this extract could prevent the diabetes and insulin resistant-associated effects on spermatogenesis in an experimentally induced diabetes rat model.

\section{North Africa}

Ajuga iva L. (Labiatae) is among the most frequently investigated antidiabetic plants from northern Africa, especially Morocco and Algeria. The hypoglycemic and hypolipidemic effects of the aqueous extract of $A$. iva have been investigated in a number of T1D models of rats [89-91]. Oral administration of the extract at $10 \mathrm{mg} / \mathrm{kg}$ bw/day reduced the plasma glucose levels by $69.73 \%$ after a 6 -hour post-treatment period and $87.3 \%$ in a subchronic dosing of 28 days in diabetic rats compared to $21.4 \%$ and $18.4 \%$ in normoglycemic rats, respectively. Furthermore, the in vivo antioxidant effects of this plant's extracts have also been reported in an STZ-induced T1D model of rats [92]. The 4-week supplementation of $0.5 \%$ aqueous extract of $A$. iva prevented oxidative damages by decreasing lipid peroxidation, and improved the activities of plasma and tissue antioxidant enzymes in experimentally induced diabetic rats. Hamden et al. [93] reported that the phytoecdysteroids rich extract of $A$. iva prevented the diabetes-associated microvascular complications in alloxan-induced diabetic rats when administered orally for fifteen days.

Allium cepa L. (Liliaceae) (onion) is widely distributed throughout the African region and is among the most cited plants from West and North Africa. The antidiabetic effect of $A$. cepa was evaluated in both animal models and human subjects [94]. Fresh crude slices (100 g) of $A$. cepa were given to type 1 and 2 diabetic human subjects. In type 1 diabetic subjects, a 50\% reduction in the blood glucose level was observed at 4 hours post-treatment compared to insulin-treated (70.8\%) patients. In type 2 diabetic subjects, about $20 \%$ reduction was observed compared to $37.5 \%$ in insulin-injected subjects [94]. It was also reported by El-Demerdash et al. [95] that $A$. cepa at a dose of $1 \mathrm{~mL}$ or $0.4 \mathrm{~g} / 100 \mathrm{~g}$ bw restored the biochemical and antioxidant status altered by alloxan injection in a T1D model of rats. The concentration of thiobarbituric acid reactive substances and the activity of glutathione S-transferase in plasma, liver, testes, brain, and kidneys were significantly increased in alloxan diabetic rats. These increases were completely prevented in A. cepa-treated rats. Various compounds were isolated and correlated positively as being responsible for the hypoglycemic effect of $A$. cepa. Phenolics and sulphur compounds, such as cysteine and allyl propyldisulphide, have been associated with this effect [94]. Some studies linked the observed hypoglycemic effects of this plant to the essential oils [96].

In Egyptian traditional medicine, Balanites aegyptiaca L. (Balanitaceae) is popularly used as an oral hypoglycemic agent. The protective effect of orally treated aqueous and ethanolic extracts at $80 \mathrm{mg} / \mathrm{kg}$ bw/day against liver damage, and hypoglycemic and hypolipidemic effects in alloxan-induced type 1 diabetic rats were investigated [97]. Liver glycogen, serum insulin, leptin, and testosterone levels were increased in treated rats while glucagon, total lipids, total cholesterol, triglyceride level, and transaminase activities were significantly decreased. In another study, oral administration of B. aegyptiaca fruit aqueous extract at $1500 \mathrm{mg} / \mathrm{kg}$ bw/day decreased fasting blood glucose by $24 \%$ compared to the diabetic control. The dose-dependent inhibition of alpha amylase and glucose-6-phosphatase activities with an increase in glucose-6-phosphate dehydrogenase and phospho-fructokinase activities were reported [98]. The TLC and HPLC fingerprints of this extract led to the identification of a marker compound, diosgenin [98].

It has been reported that Carum carvi L. (Apiaceae) has been used for medicinal purposes since ancient times [99]. Hypoglycemic and hypolipidemic effects of the aqueous fruit extract orally administered at $20 \mathrm{mg} / \mathrm{kg}$ bw/day have been evaluated in an STZ-in- 
duced T1D model of rats $[100,101]$. The extract significantly decreased the blood glucose levels by more than $50 \%$ compared to nondiabetic rats within two weeks of administration but did not increase the insulin levels of normal rats. Moreover, treatment with the extract significantly decreased the serum lipid profile levels. C. carvi has been classified as a good hypoglycemic agent with high radical scavenging activity [102]. Some of the active compounds isolated from this plant include d-limonene, benzyl alcohol, o-cresol, isomenthone, methyl chavicol, d-carvone, perillaldehyde, and $\beta$-patchoullene [102].

In Morocco, Chamaemelum nobile L. (Asteraceae) is used locally for the treatment of DM and its complications. The antihyperglycemic effect of the aqueous fruit extract administered at $20 \mathrm{mg} /$ $\mathrm{kg}$ bw/day has been reported in an obese T2D model of mice [103]. The postprandial hyperglycemia dropped significantly by more than $80 \%$, and the increase in body weight was completely prevented in mice treated with this extract. In another study, Lemhadri et al. [104] reported that the extract-treated animals demonstrated a decrease in endogenous glucose production compared to the diabetic control group. It also improved insulin sensitivity in peripheral tissues, which was confirmed by an increased glucose utilization in an STZ-induced diabetic model of mice [104].

Morus alba L. (Moraceae) (white mulberry) is another important plant used in the management of DM in northern Africa. The hypoglycemic effect of root bark flavonoid-rich fractions has been investigated [105]. The blood glucose levels of treated animals at $600 \mathrm{mg} / \mathrm{kg}$ bw for ten days dropped by about $50 \%$ compared to that of the diabetic control group. Insulin levels were significantly increased, while the peroxide levels were significantly decreased in this study. Morusin, cyclomorusin, neocyclomorusin, kuwanon E, 2-arylbenzofuran, moracinM, betulinic acid, and methylursolate were the compounds isolated from M. alba. El-Sayyad et al. [106] investigated the effect of the M. alba leaf extract on both micro- and macrovascular complications associated with DM. In their study, treatment with the extract at $100 \mathrm{mg} / \mathrm{kg}$ bw/day prevented the increase in maternal serum glucose, alterations in lipid profiles, and creatine phosphokinase activity, as well as retinal neurotransmitters including acetylcholine, adrenaline, noradrenaline, serotonin, histamine, dopamine, and gamma amino butyric acid. Furthermore, cataract and retinopathy were also prevented in the treated groups. In another study, mulberroside A, $5,7,2$-trihydroxyflavonone-4=0- $\beta$-D-glucoside, and albanols $A$ and $B$ were also isolated from fractions derived from the ethanolic root bark of M. alba [107]. The authors also indicated that oral administration of these fractions at $500 \mathrm{mg} / \mathrm{kg}$ bw/day significantly prevented the oxidative damage induced by hyperlipidemia in rats.

Nigella sativa L. (Ranunculaceae), popularly used as a spice, has also been reported to be used traditionally in the treatment of diabetes and was investigated in a number of studies [108]. The hypoglycemic potentials of $N$. sativa oil from the seed have been reported [109]. The oil significantly reduced the blood glucose levels in an STZ-induced T1D model of rats within six weeks of oral administration. It was reported by the authors that the blood glucose lowering effect might be stimulated by extra hepatic tissues rather than by insulin release. In another study, N. sativa seed extract decreased the blood glucose levels by almost $81 \%$ and normalized fructosamine, hemoglobin, and albumin levels in experimentally induced diabetic animals within 30 days of oral administration of $300 \mathrm{mg} / \mathrm{kg}$ bw [110]. The extract was able to ameliorate the diabetes-associated oxidative damages in the same study. The regulation of hepatic glycolytic and gluconeogenic enzyme activities were considered as a possible mode of action in this study. Benhaddou-Andaloussi et al. [111] have recently demonstrated the antidiabetic effect of $N$. sativa seed ethanolic extract when administered at $2 \mathrm{~g} / \mathrm{kg}$ bw/day, and which is mediated through an insulin-sensitizing action by enhancing acetyl-CoA carboxylase phosphorylation, a major component of the insulin-independent AMPK signaling pathway, and by enhancing muscle GLUT4 expression.

The antidiabetic effect of the butanol leaf extract and christinin A (a major saponin glycoside) of Ziziphus spina-christi L. (Rhamnaceae) has been investigated in both type 1 and type 2 diabetic models of rats [112,113]. In type 2 but not in the T1D model, pretreatment of both the extract and the isolated compound at $100 \mathrm{mg} / \mathrm{kg}$ bw/day indicated a clear improvement in the oral glucose tolerance test and mediated glucose-induced insulin release. Both the extract and christin A caused a significant decrease in blood glucose levels by $24 \%$ and $22 \%$, respectively, after 60 minutes, and increased serum insulin levels in a T2D model of rats. The extract was also reported to cause no damage to the kidneys, liver, or hematological parameters after 30 days of oral administration. Michel et al. [114] have also demonstrated the hypoglycemic effect of $Z$. spina-christi leaf ethanolic extract when fed orally at $200 \mathrm{mg} / \mathrm{kg} \mathrm{bw} /$ day. A significant increase in serum insulin and C-peptide levels were observed in extract-treated animals. The extract also ameliorated the oxidative damages and prevented the protein glycosylation induced by diabetes. The activities of liver glucose-6-phosphatase and alpha amylase $\left(\mathrm{IC}_{50}\right.$ of $0.3 \mathrm{mg} / \mathrm{mL}$ ) were inhibited by this extract, but significantly increased the activity of glucose 6 -phosphate dehydrogenase. HPLC and spectrophotometric determination revealed a flavonoid as a marker compound named christinin A in this plant.

\section{Southern Africa}

Artemisia afra Jacq. (Asteraceae) is mostly identified by its aromatic odor. It is widely available and is being used to treat DM. In 2011, Afolayan and Sunmonu [115] reported that the orally administered aqueous leaf extract at 50 and $100 \mathrm{mg} / \mathrm{kg}$ bw/day significantly decreased the blood glucose levels by more than $50 \%$ compared to the diabetic control, with a concomitant increase in insulin levels. The extract also showed a high antioxidant effect by increasing the levels of antioxidant enzymes and decreasing lipid peroxidation. Similar effects of the extract on antioxidant defense systems in the liver and kidneys were also observed within three weeks of oral administration at the same doses in diabetic animals [116].

Bryophyllum pinnatum Lam. (Crassulaceae), popularly known as "good luck" or "life plant" is widely used in the management of DM by the majority of the African populace. Ojewole [117] has reported the antidiabetic, antinociceptive, and anti-inflammatory effects of $B$. pinnatum in rats using fresh egg albumin-induced pedal (paw) edema, and in an STZ-induced T1D model of rats. B. pinnatum leaf aqueous extract treated orally at $400 \mathrm{mg} /$ $\mathrm{kg}$ bw significantly and dose-dependently decreased fasting blood glucose in diabetic rats by almost $50 \%$ within 8 hours. A similar effect was observed in albumin-induced acute inflammation of the rat hind paw.

Raphia gentiliana De Wild. (Arecaceae) is one of the most popular plants used in the treatment of several disease ailments in the Democratic Republic of Congo. Its fruits are commonly consumed as food. The hypoglycemic effect of the aqueous fruit extract has been investigated in normoglycemic human subjects and glu- 
cose-induced hyperglycemic animals [118]. After one and two hours post-treatment at $200 \mathrm{mg} / \mathrm{kg}$ bw, the fasting blood glucose dropped by $27 \%$ and $56 \%$, respectively, in diabetic mice. In human subjects, the glycemic index (signifying glucose absorbed into the blood after a meal) and load index (total glucose content in normal subjects) recorded were $-3.60 \%$ and $-1.36 \%$, respectively, which are within the recommended range. The results indicate the preventive role of $R$. gentiliana fruit in glucose absorption, which could be associated with the active principles present in the fruit extract.

The stem bark, roots, and leaves of Sclerocarya birrea A. Rich. Hochst. (Anacardiaceae) are widely used in South Africa and African countries as folk medicine in the treatment DM. The hypoglycemic effect of the stem bark aqueous extract has been investigated in normal and STZ-induced diabetic rats $[119,120]$. S. birrea stem bark aqueous extract at $800 \mathrm{mg} / \mathrm{kg}$ bw significantly and dose-dependently decreased the fasting blood glucose in both normal and diabetic-treated rats, with a maximum reduction capacity of $50.16 \%$, which was comparable with that of chlorpropamide (62.44\%) after 8 hours post-oral treatment. Furthermore, Musabayane et al. [121] previously established the beneficial effect of the $S$. birrea stem bark aqueous extract treated orally at various doses $(60,120$, and $240 \mathrm{mg} / \mathrm{kg}$ bw) on markers of kidney and cardiovascular functions in diabetic rats. It significantly decreased the blood glucose levels and the levels of $\mathrm{Na}^{+}$and $\mathrm{K}^{+}$ion excretion rates, which were not altered by short-term or prolonged exposure to the extract. The same research group reported that the ethanolic stem bark extract at the same dosages improved blood glucose, the glomerular filtration rate, and mean arterial blood pressure in an STZ-induced T1D model of rats [122].

Sutherlandia frutescens R. BR., variety incana E. MEY., (Fabaceae) is among the most common and widely used plants in the southern part of Africa for the treatment of DM and its associated complications. The hypoglycemic effect of $S$. frutescens has been investigated [123]. The shoots aqueous extract significantly prevented the STZ-induced hyperglycemic condition in mice when administered orally at various dosages ( $50-800 \mathrm{mg} / \mathrm{kg}$ bw). In another study, Chadwick et al. [124] reported that S. frutescens is a potential agent in the management of DM, especially type $2 \mathrm{DM}$. The aqueous leaf extract-treated rats showed an increase in glucose uptake and utilization by peripheral tissues with a decrease in intestinal glucose absorption. Glucose uptake was carried out using $\left[{ }^{3} \mathrm{H}\right]$ deoxy-glucose. The $\left[{ }^{3} \mathrm{H}\right]$ deoxy-glucose count increased significantly in muscle and epididymal fat tissues when treated with the $S$. frutescens shoot aqueous extract in a diet-induced T2D model of rats, and the results were comparable with metformin-treated rats. In a different study, S. frutescens prevented insulin resistance and showed a hypolipidemic effect in diabetic rats [125]. The plasma free fatty acid dropped significantly. Similarly, the homeostatic model assessment (HOMA-IR) and quantitative insulin sensitivity check index (QUICKI) demonstrated that oral treatment of the extract at $50 \mathrm{mg} / \mathrm{kg}$ bw prevented the development of insulin resistance in a high-fat dietfed insulin-resistance model of rats.

\section{Central Africa}

Bersama engleriana (Melianthaceae) is commonly available in almost all African regions and has been traditionally used in the management of DM. To evaluate such a claim, preliminary hypoglycemic effects of both aqueous and methanolic leaf extracts at 300 and $600 \mathrm{mg} / \mathrm{kg}$ bw/day were reported in normoglycemic rats
[126]. At the $600 \mathrm{mg}$ dose, blood glucose levels dropped by $37.7 \%$ and $49.11 \%$ for aqueous and methanolic extracts, respectively. To expand upon this study, Watcho et al. [127] investigated the effect of this plant on STZ/nicotinamide T2D models of rats. The leaf aqueous and methanolic extracts treated orally at 400 and $600 \mathrm{mg} / \mathrm{kg}$ bw/day significantly and dose-dependently decreased the blood glucose levels and lipid profile with an increase in HDL cholesterol levels. At the $600 \mathrm{mg}$ dose, the ethanolic extract demonstrated a higher reduction of blood glucose levels $(80.31 \%)$ compared to the aqueous extract (67.74\%). The decrease in organ weight recorded in diabetic-untreated rats was completely prevented in the extract-treated groups.

Dichrostachys glomerata Chiov. (Cucurbitaceae) is a spice used in the management of DM and its associated complications. Because of its strong antioxidant action, the effect of $D$. glomerata on various cardiovascular disease risk factors in obese normoglycemic and obese type 2 diabetic human subjects has been reported [128]. Dried pods were supplied daily in the form of capsules containing $400 \mathrm{mg}$ D. glomerata 30-60 minutes before lunch and dinner. The results of the study indicated a decrease in body weight by $7.91 \%$ in obese normoglycemic and $5.97 \%$ in obese type 2 diabetic subjects. Similarly, the reduction of BMI, waist and hip circumference, body fat, blood pressure, blood cholesterol, triglycerides, glucose, and glycosylated hemoglobin was higher in the normoglycemic subjects compared to the obese type 2 diabetic subjects. The results confirmed the traditional claims that $D$. glomerata could ameliorate the complications associated with DM and other related cardiovascular diseases.

Although rarely investigated, an important complication associated with DM in men is infertility or erectile dysfunction [129]. As a result, Wankeu-Nya et al. [130] investigated the possible antidiabetic effect of aqueous and ethanolic root bark extracts of Dracena arborea Wild. (Dracaenaceae), which has been widely acclaimed for its aphrodisiac action in Cameroonian traditional medicine. The antihyperglycemic effect was observed in an STZinduced T1D model of rats, with no such effect on normoglycemic rats. Oral treatment at $500 \mathrm{mg} / \mathrm{kg}$ bw of aqueous extract and $100 \mathrm{mg} / \mathrm{kg}$ bw of ethanolic extract for three weeks ameliorated the severe damages of the testes morphology and spermatogenesis, as observed in the diabetic-untreated rats. Although an increase in blood glucose was observed in both the aqueous (15.39\%) and ethanolic extract (19.04\%) -treated animals, this increase was lower than that of the untreated animals (>60.34\%). Flavonoids, sterols, and saponins were some of the compounds qualitatively determined to be present in both extracts.

Kalanchoe crenata Andr. Haw. (Crassulaceae) is among the most widely used plants in Cameroon and other central African countries for therapeutic purposes. Kamgang et al. [131] have reported that the aqueous-ethanol extract significantly, but not dose-dependently, decreased the blood glucose levels of diet-induced type 2 diabetic rats within six hours and four weeks of oral treatment at $200 \mathrm{mg} / \mathrm{kg}$ bw/day. The percentage of decrease recorded after four weeks was $52 \%$. The diabetic-treated rats also showed an improvement in insulin sensitivity, a decrease in body weight, and reduced water intake. In another study, Fondjo et al. [132] investigated the antidyslipidemic and antioxidant effects of K. crenata whole plant methanolic extract in an STZ-induced T1D model of rats. The extract treated orally at 50 and $68 \mathrm{mg} / \mathrm{kg} \mathrm{bw} /$ day showed a decrease in serum, liver, and kidney malondialdehyde levels, with an increase in activities of antioxidant enzymes. The glycemic reduction in treated animals was $35 \%$ and $44 \%$ for 50 and $68 \mathrm{mg} / \mathrm{kg}$ bw, respectively, after the 6-week post-treat- 
ment period. All diabetic-treated animals showed a decrease in lipid parameters, with an increase in HDL cholesterol levels and an overall reduction of the atherogenic index by $31 \%$.

\section{East Africa}

Caylusea abyssinica Fresen. Fisch. \& Mey. (Resedaceae) is popularly used in different East African countries for the management of DM, especially in Ethiopian folklore medicine. Tamiru et al. [133] reported the hypoglycemic effect of the methanolic leaf extract of $C$. abyssinica in a normal, glucose-loaded, and STZ-induced T1D model of rats when administered orally at 100, 200, and $300 \mathrm{mg} / \mathrm{kg}$ bw. In an oral glucose tolerance test, the extracttreated rats indicated a better glucose handling ability than the diabetic controls. A reduction of $52.2 \%, 62.3 \%$, and $52.8 \%$ in glycemia was achieved at the fourth hour of treatment at 100,200, and $300 \mathrm{mg} / \mathrm{kg}$ bw, respectively.

The hypoglycemic effect of five Kenyan medicinal plants in alloxanized mice has been reported [134]. These plants include Strychnos henningsii Gilg. (Loganiaceae), Erythrina abyssinica Lam. (Fabaceae), Aspilia pluriseta Schweinf. (Asteraceae), Bidens pilosa L. (Asteraceae), and Catha edulis (Vahl) Forssk. ex Endl. (Celastraceae). All the extracts showed a significant and dose-dependent blood glucose lowering activity within the 4-h posttreatment period at 50,100, and $150 \mathrm{mg} / \mathrm{kg}$ bw. The hypoglycemic effect of $C$. edulis was much better compared to others when given at a dose of $150 \mathrm{mg} / \mathrm{kg}$ bw and was as effective as insulin. Polyphenols were the major active components detected in the various parts of the plants under this study. Based on the toxicity study conducted for various parts of these plants, at higher dosages, aqueous extracts from the stem bark of $E$. abyssinica, the root bark of $C$. edulis, and B. pilosa leaves were nephrotoxic as well as hepatotoxic. S. henningsii leaves were moderately toxic while A. pluriseta root bark was reported as safe during these studies.

Momordica charantia L. (Cucurbitaceae) is one of the plants commonly used as food and in therapeutic purposes by both diabetic and healthy people, and has been known in traditional medicine for its glucose-lowering action worldwide [135]. Its fruit has a distinguished bitter taste, which is more pronounced as it ripens; hence, it is named bitter melon. A study reported by Matheka et al. [136] demonstrated that the oral administration of fresh fruit juice extract of $M$. charantia by gastric gavage at $10 \mathrm{ml} / \mathrm{kg}$ bw decreased blood glucose levels significantly by about 30 and $10 \%$ after 30 and 90 minutes, respectively, in a T1D model of rats.

Moringa stenopetala Baker f. (Moringaceae) is acclaimed for its glucose-lowering ability in Ethiopian traditional medicine. Nardos et al. [137] reported the antidiabetic effect of the leaf extracts and fractions of $M$. stenopetala in an alloxan-induced T1D model of rats. The extracts and fractions intraperitoneally administered at $300 \mathrm{mg} / \mathrm{kg}$ bw decreased blood glucose levels significantly by nearly $20 \%$ after an 8 -day post-treatment period. The ethanolic extract was safe up to $5 \mathrm{~g} / \mathrm{kg}$ bw. Furthermore, Toma et al. [138] demonstrated both antihyperglycemic and antihyperlipidemic effects with a daily oral administration of butanol fraction from the leaf ethanolic extract of M. stenopetala for four weeks in an alloxan-induced T1D rat model.

\section{Conclusion}

$\nabla$

Apart from the folkloric claims, it is evident from the above reviewed studies that Africa is blessed with an abundance of antidiabetic plants resources based on scientific findings. However, due to the variations in the scientific investigations in terms of analyzed antidiabetic parameters, doses, and durations used, it is difficult to precisely identify the plant(s) with the best reported activity, but our close analysis of the reports seem to suggest that $O$. gratissimum, A. occidentale, V. amygdalina, G. latifolium, A. indica, C. carvi, M. alba, and A. iva are the most active because they received much attention as is evident by numerous studies and, thus, possibly contain the most bioactive antidiabetic phytochemicals among all the plants. The methods mostly utilized for the extractions of various parts via organic solvent extractions include maceration/cold extraction, soxhlet, distillation, percolation, and sequential extraction. Moreover, it is evident that very few studies were reported to involve human subjects. Most studies used either T1D or T2D animal models. Unfortunately, perhaps due to limited research resources, most of the studies are preliminary in nature (though with promising results) and do not include detailed isolation and characterization of the bioactive compounds and/or the mechanisms of antidiabetic actions. Government agencies and/or pharmaceutical industries should support more research activities in this area in order to commercially utilize these antidiabetic medicinal plants for a solution to the continent's myriad of economic problems.

\section{Methodology}

$\nabla$

Relevant literatures were collected by searching the major scientific databases including Pubmed, ScienceDirect, Medline, and Google Scholar for medicinal plants of African origin that have been studied and investigated for their antidiabetic therapeutic potentials in vivo. Some articles were found through tracking citations from other publications or by directly accessing the journals' website. They were considered on the basis of the geographical region of their origin. The literature considered were those available covering the period January 2000 to July 2013. The keyword combinations for the search were antidiabetic, antihyperglycemia, hypoglycemia, medicinal plant, and Africa. Supplementary information was obtained by using another keyword combination such as plant, hypoglycemia, and Africa. A total of 313 articles were retrieved in this review, out of which 256 research articles that reported in vivo, and not in vitro, activity were selected and presented in this review. Following the search, the plants were categorized and presented based on their regional origins.

\section{Acknowledgements \\ $\nabla$}

This study was supported by the Competitive Research Grant from the Research Office, University of KwaZulu-Natal (UKZN), Durban, an Incentive Grant for Rated Researchers, and Grant Support for Women and Young Researchers from the National Research Foundation (NRF), Pretoria, South Africa. The first author was awarded a PhD study scholarship by the Education Trust Fund desk office, Ahmadu Bello University, Zaria, Nigeria. 


\section{Conflict of Interest}

\section{$\nabla$}

There is no conflict of interest within this article.

\section{Reference}

1 Neelesh M, Sanjay J, Sapna M. Antidiabetic potential of medicinal plants. Acta Pol Pharm 2010; 67: 113-118

2 Maritim AC, Sander RA, Watkins JB. Diabetes, oxidative stress, and antioxidants: a review. J Biochem Mol Toxicol 2003; 17: 24-38

3 Whiting DR, Guariguata L, Weil C, Shaw J. IDF diabetes atlas: global estimates of the prevalence of diabetes for 2011 and 2030. Diabet Res Clin Pract 2011; 94: 311-321

4 International Diabetes Federation (Brussels). Diabetes at a glance, 2012, Africa (AFR). Available at https://www.idf.org/sites/default/files/IDF_ AFR_5E_Update_FactSheet_0.pdf. Accessed February 13, 2013.

5 Michael PK, Asim AB, Robert SB. The utility of oral diabetes medications in type 2 diabetes of the young. Curr Diabet Rev 2005; 1: 83-92

6 Cragg GM, Newman DJ. Natural products: a continuing source of novel drug leads. Biochim Biophys Acta 2013; 1830: 3670-3695

7 Zhang $X$. Legal status of traditional medicines and complementary/alternative medicine. A worldwide review. World Health Organ Tech Rep Sep 2001; 2: 5-41

8 Zhang BB, Moller DE. New approaches in the treatment of type 2 diabetes. Curr Opin Chem Biol 2000; 4: 461-467

9 Calixto JB. Efficacy, safety, quality control, marketing and regulatory guidelines for herbal medicines (phytotherapeutic agents). Braz J Med Biol Res 2000; 33: 179-189

10 Van Wyk BE, deWetb H, Van Heerden FR. An ethnobotanical survey of medicinal plants in the south-eastern Karoo, South Africa. S Afr J Bot 2008; 74: 696-704

11 Adebayo AG. Inventory of antidiabetic plants in selected districts of Lagos State, Nigeria. J Ethnopharmacol 2009; 121: 135-139

12 N'guessa K, Kouassi K, Kouadio K. Ethnobotanical study of plants used to treat diabetes, in traditional medicine, by Abbey and Krobou people of Agboville (Côte-d'Ivoire). Am J Sci Res 2009; 4: 45-58

13 Keter LK, Mutiso PC. Ethnobotanical studies of medicinal plants used by traditional health practitioners in the management of diabetes in lower eastern province, Kenya. J Ethnopharmacol 2012; 139: 74-80

14 Moshi MJ, Mbwambo ZH. Experience of Tanzanian traditional healers in the management of non-insulin dependent diabetes mellitus. Pharm Biol 2002; 40: 552-560

15 Rutebemberwa E, Lubega M, Katureebe SK, Oundo A, Kiweewa F, Mukan$\mathrm{ga} D$. Use of traditional medicine for the treatment of diabetes in Eastern Uganda: a qualitative exploration of reasons for choice. BMC Int Health Hum Rights 2013; 13: 2-7

16 Rachid A, Rabah D, Farid L, Zohra SF, Houcine B, Nacéra B. Ethnopharmacological survey of medicinal plants used in the traditional treatment of diabetes mellitus in the North Western and South Western Algeria. J Med Plants Res 2012; 6: 2041-2050

17 Bnouham M, Mekhfi H, Legssyer A, Ziyyat A. Ethnopharmacology forum medicinal plants used in the treatment of diabetes in Morocco. Int J Diabet Metab 2002; 10: 33-50

18 Eddouks M, Maghrani M, Lemhadri A, Ouahidi ML, Jouad H. Ethnopharmacological survey of medicinal plants used for the treatment of diabetes mellitus, hypertension and cardiac diseases in the south-east region of Morocco (Tafilalet). J Ethnopharmacol 2002; 82: 97-103

19 Afolayan AJ, Sunmonu TO. In vivo Studies on Antidiabetic Plants Used in South African Herbal Medicine. J Clin Biochem Nutr 2010; 47: 98-106

20 Mahop TM, Mayet M. Enroute to biopiracy? Ethnobotanical research on antidiabetic medicinal plants in the Eastern Cape Province, South Africa. Afr J Biotechnol 2007; 6: 2945-2952

21 Din N, Dibong SD, Mpondo E, Priso RJ, Kwin NF, Ngoye A. Inventory and identification of plants used in the treatment of diabetes in Douala Town (Cameroon). Eur J Med Plants 2011; 1: 60-73

22 Olatunji LA, Okwusidi JI, Soladoye AO. Antidiabetic effect of Anacardium occidentale stem-bark in fructose-diabetic rats. Pharm Biol 2005; 43: 589-593

23 Abdullahi S, Olatunji GA. Antidiabetic activity of Anacardium occidentale in alloxan - diabetic rats. J Sci Technol 2010; 30: 35-41

24 Fagbohun TR, Odufunwa KT. Hypoglycemic effect of methanolic extract of Anacardium occidentale leaves in alloxan-induced diabetic rats. Niger J Physiol Sci 2010; 25: 87-90

25 Ukwenya VO, Ashaolu JO, Adeyemi DO, Akinola OB, Caxton-Martins EA. Antihyperglycemic activities of methanolic leaf extract of Anacardium occidentale (Linn.) on the pancreas of streptozotocin-induced diabetic rats. J Cell Anim Biol 2012; 6: 207-212

26 Koffour GA, Amoatengor P, Okai CA, Fiagbe NIY. Hypoglycemic effects of whole and fractionated Azadirachta indica (Neem) seed oils on alloxan-induced diabetes in New Zealand white rabbits. J Ghana Sci Assoc 2011; 13: 34-39

27 Henry DA, Itemobong SE, Itoro FU, Patrick EE, Isong NB. Effect of aqueous extract of Azadirachta indica (Neem) leaves on some indices of pancreatic function in alloxan-induced diabetic Wister rats. Pharmacologia 2012; 3: 420-425

28 Akinola OB, Zatta L, Dosumu OO, Akinola OS, Adelaja AA, Dini L, CaxtonMartins EA. Intestinal lesions of streptozotocin-induced diabetes and the effects of Azadirachta indica treatment. Pharmacology 2009; 3: 872-881

29 Akinola OB, Caxton-Martins EA, Dini L. Chronic treatment with ethanolic extract of the leaves of Azadirachta indica ameliorates lesions of pancreatic islets in streptozotocin diabetes. Int J Morphol 2010; 28: 291-302

30 Akinola OB, Zatta L, Dosumu OO, Akinola OS, Dini L, Caxton-Martins EA. Ameliorative effects of ethanolic leaves extract of Azadirachta indica on renal histologic alterations streptozotocin-induced diabetic rats. Am J Chin Med 2011; 39: 903-916

31 Itemobong SE, Item JA, Henry DA, Itoro FU, Oboso EE, Patrick EE. Effects of ethanol extract of Azadirachta indica leaves on some immunological and haematological parameters of diabetic Wistar rats. Afr J Pharm Pharmacol 2010; 4: 104-108

32 Nwanjo HU, Okafor MC, Oze GO. Anti-lipid peroxidative activity of Gongronema latifolium in streptozotocin-induced diabetic rats. Niger J Physiol Sci 2006; 21: 61-65

33 Johnkennedy N, Adamma E, Augustin I, Ifeoma UH. Influence of Gongronema latifolium on some biochemical parameters in alloxan induced diabetes. Int J Anal Pharm Biomed Sci 2012; 1: 13-17

34 Ibegbulem CO, Chikezie PC. Hypoglycemic properties of ethanolic extracts of Gongronema latifolium, Aloe perryi, Viscum album and Allium sativum administered to alloxan induced diabetic albino rats (Rattus norvegicus). J Biol Chem Res 2012; 29: 16-25

35 Francis VU, Grace AE, Jones OA, Frank EE. Hypoglycemic effect of Gongronema latifolium extracts in rats. J Nat Sci Res 2013; 3: 37-44

36 Akah PA, Uzodinma SU, Okolo CE. Antidiabetic activity of aqueous and methanol extract and fractions of Gongronema latifolium (Asclepidaceae) leaves in alloxan diabetic rats. J Appl Pharm Sci 2011; 1: 99-102

37 Edet EE, Akpanabiatu MI, Eno AE, Umoh IB, Itam EH. Effect of Gongronema latifolium crude leaf extract on some cardiac enzymes of alloxaninduced diabetic rats. Afr J Biochem Res 2009; 3: 366-369

38 Adebajo AC, Ayoola MD, Odediran SA, Aladesanmi AJ, Schmidt TJ, Verspohl EJ. Evaluation of ethnomedical claim III: anti-hyperglycaemic activities of Gongronema latifolium root and stem. J Diabet 2013; 5: 336343

39 Orok UE, Eneji EG, Luke OU, Eyo RA, Sampson EV, Iwara IA, Oko OM. Effect of ethanolic root and twig extracts of Gongronema latifolium (utazi) on kidney function of streptozotocin induced hyperglycemic and normal Wistar rats. J Med Med Sci 2012; 3: 291-296

40 Sini JM, Umar IA, Inuwa HM. The beneficial effect of extract of Hibiscus sabdariffa calyces in alloxan-diabetic rats: Hypoglycaemic and hypolipidaemic activities. J Med Plants Res 2011; 5: 2182-2186

41 Sini JM, Umar IA, Inuwa HM. The beneficial effect of extract of Hibiscus sabdariffa calyces in alloxan-diabetic rats: Reduction of free radical load and enhancement of antioxidant status. J Pharmacogn Phytother 2011; 3: 141-149

42 Adedayo OA, Ganiyu O. Aqueous extracts of roselle (Hibiscus sabdariffa Linn.) varieties inhibit $\alpha$-amylase and $\alpha$-glucosidase activities in vitro. J Med Food 2013; 16: 88-93

43 Tanko Y, Abdelaziz MM, Adelaiye AB, Fatihu MY, Musa KY. Effects of hydromethanolic leaves extract of Indigofera pulchra on blood glucose levels of normoglycemic and alloxan-induced diabetic Wistar rats. Int J Appl Res Nat Prod 2009; 1: 13-18

44 Tanko Y, Hayatu Z, Mohammed A, Goji ADT, Musa KY, Yerima M. Effect of Residual Aqueous Portion of Hydro-methanolic Leaves Extract of Indigofera pulchra on blood glucose Levels of alloxan-induced diabetic Wistar rats. Int J Anim Vet Adv 2009; 1: 18-21

45 Tanko Y, Abdelaziz MM, Adelaiye AB, Fatihu MY, Musa KY. Effects of ethyl acetate portion of Indigofera pulchra leaves extract on blood glucose levels of alloxan-induced diabetic and normoglycemic Wistar rats. Asian J Med Sci 2009; 1: 10-14 
46 Tanko Y, Mabrouk MA, Adelaiye AB, Fatihu MY, Musa KY. Anti-diabetic and some haematological effects of ethylacetate and n-butanol fractions of Indigofera pulchra extract on alloxan-induced diabetic Wistar rats. J Diabet Endocrinol 2011; 2: 1-7

47 Gidado A, Ameh DA, Atawodi SE. Effect of Nauclea latifolia leaves aqueous extracts on blood glucose levels of normal and alloxan-induced diabetic rats. Afr J Biotechnol 2005; 4: 91-93

48 Gidado A, Ameh DA, Atawodi SE, Ibrahim S. Hypoglycaemic activity of Nauclea latifolia SM. (Rubiaceae) in experimental animals. Afr J Tradit Complement Alternat Med 2008; 5: 201-208

49 Gidado A, Ameh DA, Atawodi SE, Ibrahim S. A preliminary study of the mechanism of hypoglycaemic activity of Nauclea latifolia leaf ethanolic extract. J Complement Integr Med 2012; DOI: 10.1515/15533840.1561

50 Yessoufou A, Gbenou J, Grissa O, Hitchami A, Simonin A, Tabka Z, Moudachirou M, Mountairou K, Khan N. Anti-hyperglycemic effects of three medicinal plants in diabetic pregnancy: modulation of $\mathrm{T}$ cell proliferation. BMC Complement Alternat Med 2013; 13: 77

51 Grace SE, Bob IAM, Godwin OI, Justin IA, Eyong UE, Patrick EE. Antioxidant enzymes activity and hormonal changes following administration of ethanolic leaves extracts of Nauclea latifolia and Gongronema latifolium in streptozotocin induced-diabetic rats. Eur J Med Plants 2013; 3 : 297-309

52 Seung-Joo-Lee KU, Takayuki S, Kwang-Guen L. Identification of volatile components in basil (Ocimum basilicum) and thyme leaves (Thymus vulgaris) and their antioxidant properties. Food Chem 2004; 91: 131137

53 Aguiyi JC, Obi CI, Gang SS, Igweh AC. Hypoglycaemicactivity of Ocimum gratissimum in rats. Fitoterapia 2000; 71: 444-446

54 Onaolapo AY, Onaolapo OJ, Adewole SA. Ethanolic extract of Ocimum grattissimum leaves (Linn.) rapidly lowers blood glucose levels in diabetic Wistar rats. Macedonia J Med Sci 2011; 4: 351-357

55 Egesie UG, Adelaiye AB, Ibu JO, Egesie OJ. Safety and hypoglycaemic properties of aqueous leaf extract of Ocimum gratissimum in streptozotocin induced diabetic rats. Niger J Physiol Sci 2006; 21: 31-35

56 Mohammed A, Tanko Y, Okasha MA, Magaji RA, Yaro AH. Effects of aqueous leaves extract of Ocimum gratissimum on blood glucose levels of streptozocin-induced diabetic Wister rats. Afr J Biotechnol 2007; 6: 2087-2090

57 Asuquo OR, Edet AG, Mesembe O, Atanghwo J. Ethanolic extracts of Vernonia amygdalina and Ocimum gratissimum enhance testicular improvement in diabetic wistar rats. Internet J Altern Med 2010; DOI: $10.5580 / 89 d$

58 Joyce 00, Nworah DC, Egwurugwu JN, Pughikumo DT, Joffa PPK. Comparative anti-diabetic effects of Ocimium gratissimum, Vernonia amygdalina and insulin on testicular architecture in STZ-induced diabetic rats. Am J Pharm Tech Res 2012; 2: 279-287

59 Oguanobi NI, Chijioke CP, Ghasi S. Anti-diabetic effect of crude leaf extracts of Ocimum gratissimum in neonatal streptozotocin-induced type-2 model diabetic rats. Int J Pharm Pharm Sci 2012; 5: 77

60 Okon UA, Ikpi DE, Ben EE. Ocimum gratissimum alleviates derangements in serum and biliary bilirubin, cholesterol and electrolytes in streptozotocin induced diabetic rats. Int J Biochem Res Rev 2013; 3: 171-189

61 Herbert OCM, Clement J, Idongesit J, Godwin E, Udeme E, Grace E. Evaluation of the hypoglycemic effect of aqueous extract of Phyllanthus amarus in alloxan-induced diabetic albino rats. Int J Pharm Biomed Res $2011 ; 2: 158-160$

62 Owolabi OA, James DB, Anigo KM, Iormanger GW, Olaiya II. Combined effect of aqueous extracts of Phyllanthus amarus and Vitex doniana stem bark on blood glucose of streptozotocin (STZ) induced diabetes rats and some liver biochemical parameters. Br J Pharmacol Toxicol $2011 ; 2: 143-147$

63 Povi L, Kwashie E, Amegnona A, Kodjo A, Edmond C, Messanvi G. Antidiabetic activity of Phyllanthus amarus Schum and Thonn (Euphorbiaceae) on alloxan induced diabetes in male Wistar rats. J Appl Sci 2011; 11: 2968-2973

64 Adeneye AA. The leaf and seed aqueous extract of Phyllanthus amarus improves insulin resistance diabetes in experimental animal studies. J Ethnopharmacol 2012; 144: 705-711

65 Aguwa CN, Ukwe CV, Inya-Agha SI, Okonta JM. Antidiabetic effect of Picralima nitida aqueous seed extract in experimental rabbit model. J Nat Rem 2001; 1: 135-139

66 Igboasoiyi AC, Essien EE, Eseyin OA, Ubam G. Screening of the seed of Picralima nitida for hypoglycaemic activity. Pak J Biol Sci 2007; 10: $828-830$
67 Nimenibo-Uadia $R$. Effects of Vernonia amygdalina in alloxan-induced diabetic albino rats. J Med Lab Sci 2003; 12: 25-31

68 Chike CPR, Georgewill OA, Nnodi CU. Effect of aqueous leaf extract of Vernonia amygdalina (bitter leaf) on blood glucose concentration of alloxan induced diabetic albino Wistar rats. Afr J Appl Zool Environ Biol 2006; 8: 44-47

69 Osinubi AA. Effects of Vernonia amygdalina and chlorpropamide on blood glucose. Med J Islamic World Acad Sci 2007; 16: 115-119

70 Iwuji SC, Nwafor A, Adienbo OM, Egwurugwu J, Iwuji NG, Oodo OM. Hypoglycaemic potential of aqueous leaf extract of Vernonia amygdalina: An Animal Model. Afr J Med Physiol Biomed Eng Sci 2010; 2: 9-13

71 Taiwo IA, Odeigah PGC, Ogunkanmi LA. The glycaemic effects of Vernonia amygdalina and $V$. tenoreana with tolbutamide in rats and the implications for the treatment of diabetes mellitus. J Sci Res Dev 2008; 11 : $122-130$

72 Fasola TR, Okeocha PC, Odetola A. Screening for the hypoglycaemic potentials of the extract of Vernonia amygalina. Ethnobot Leaflets 2010; 14: 759-765

73 Owen OJ, Amakiri AO, Karibi-Botoye TA. Sugar-lowering effects of bitter leaf (Vernonia amygdalina) in experimental broiler finisher chickens. Asian J Pharm Clin Res 2011; 4: 19-21

74 Modu SA, Adeboye E, Maisaratu A, Mubi BM. Studies on the administration of Vernonia amygdalina Del. (Bitter leaf) and glucophage on blood glucose level of alloxan-nduced diabetic rats. Int J Med Plant Altern Med 2013; 1: 13-19

75 Okolie UV, Okeke CE, Oli JM, Ehiemere IJ. Hypoglycemic indices of Vernonia amygdalina on postprandial blood glucose concentration of healthy humans. Afr J Biotechnol 2008; 7: 4581-4585

76 Atangwho IJ, Ebong PE, Eteng MU, Eyong EU, Obi AU. Effect of Vernonia amygdalina Del leaf on kidney function of diabetic rats. Int J Pharmacol 2007; 3: 143-148

77 Eteng MU, Bassey BJ, Atangwho IJ, Egbung GE, Eyoung EU, Ebong PE, Abolaji AO. Biochemical indices of macrovascular complication in diabetic rat model: compared effects of Vernonia amygdalina, Catharantus roseus and chlorpropamide. Asian J Biochem 2008; 3: 228-234

78 Akah PA, Alemji JA, Salawu OA, Okoye TC, Offiah NV. Effects of Vernonia amygdalina on biochemical and hematological parameters in diabetic rats. Asian J Med Sci 2009; 1: 108-113

79 Atangwho IJ, Eyong EU, Ebong PE, Egbung GE. Effects of combined administration of Vernonia amygdalina (Del.) and Azadirachta indica (A. Juss) extracts on compartmental glucose concentration and $\alpha$-amylase activity of diabetic and non-diabetic rats. Niger J Biochem Mol Biol 2009; 24: 22-28

80 Atangwho IJ, Ebong PE, Eyong EU, Ashmawi MZ, Ahmad M. Synergistic antidiabetic activity of Vernonia amygdalina and Azadirachta indica: biochemical effects and possible mechanism. J Ethnopharmacol 2012; 141: 878-887

81 Akpaso MI, Atangwho IJ, Akpantah A, Fischer VA, Igiri AO, Ebong PE. Effect of combined leaf extracts of Vernonia amygdalina (Bitter leaf) and Gongronema latifolium (Utazi) on the pancreatic $\beta$-Cells of streptozotocin induced diabetic rats. Br J Med Med Res 2011; 1: 24-34

82 Okokon JE, Umoh UF, Ekpo BAJ, Etim EI. Antidiabetic study of combined extracts of Vernonia amygdalina, Ocimum gratissimum, and Gongronema latifolium on alloxan-induced diabetic rats. J Nat Pharm 2013; 4: $28-31$

83 Kalejaiye OF, Iwalewa EO, Omobuwajo OR, Oyedapo 00. Hypoglycaemic effects of Nigerian Zingiber officinale rhizome on experimental diabetic rats. Niger J Nat Prod Med 2002; 6: 32-35

84 Ozougwu JC, Eyo JE. Evaluation of the activity of Zingiber officinale (ginger) aqueous extracts on alloxan-induced diabetic rats. Pharmacology 2011; 1: 258-269

85 Eyo JE, Ozougwo JC, Echi PC. Hypoglycaemic effects of Allium cepa, Allium sativum and Zingiber officinalle aqueous extracts on alloxan-induced diabetic Rattus novergicus. Med J Islamic World Acad Sci 2011; 19: $121-126$

86 Iranloye BO, Arikawe AP, Rotimi G, Sogbade AO. Anti-diabetic and antioxidant effects of Zingiber Officinale on alloxan-induced and insulinresistant diabetic male rats. Niger J Physiol Sci 2011; 26: 89-96

87 Morakinyo AO, Akindele AJ, Ahmed Z. Modulation of antioxidant enzymes and inflammatory cytokines: possible mechanism of anti-diabetic effect of ginger extracts. Afr J Biomed Res 2011; 14: 195-202

88 Arikawe AP, Daramola AO, Olatunji-Bello II, Obika LF. Insulin, pioglitazone and Zingiber officinale administrations improve proliferating cell nuclear antigen immunostaining effects on diabetic and insulin resistant rat testis. J Exp Clin Med 2013; 30: 49-55 
89 Hilaly JE, Lyoussi B. Hypoglycaemic effect of the lyophilised aqueous extract of Ajuga iva in normal and streptozotocin diabetic rats. J Ethnopharmacol 2002; 80: 109-113

90 Hilaly JE, Tahraoui A, Israili ZH, Lyoussi B. Hypolipidemic effects of acute and sub-chronic administration of an aqueous extract of Ajuga iva L. whole plant in normal and diabetic rats. J Ethnopharmacol 2006; 105: 441-448

91 Hilaly JE, Tahraoui A, Israili ZH, Lyoussi B. Acute hypoglycemic, hypocholesterolemic and hypotriglyceridemic effects of continuous intravenous infusion of a lyophilised aqueous extract of Ajuga iva $\mathrm{L}$. Schreber whole plant in streptozotocin-induced diabetic rats. Pak J Pharm Sci 2007; 20: 261-268

92 Taleb-Senouci D, Ghomari H, Krouf D, Bouderbala S, Prost J, Lacaille-Dubois MA, Bouchenak M. Antioxidant effect of Ajuga iva aqueous extract in streptozotocin-induced diabetic rats. Phytomedicine 2009; 16: 623-631

93 Hamden K, Ayadi F, Jamoussi K, Masmuodi H, Elfeki A. Therapeutic effect of phytoecdysteroids rich extract from Ajuga iva on alloxan induced diabetic rats liver, kidney and pancreas. Biofactors 2008; 33 : $165-175$

94 Taj Eldin IM, Ahmed EM, Abd Elwahab HM. Preliminary study of the clinical hypoglycemic effects of Allium cepa (Red Onion) in type 1 and type 2 diabetic patients. Env Health Insights 2010; 4: 71-77

95 El-Demerdash FM, Yousef MI, Abou-El-Naga NI. Biochemical study on the hypoglycemic effects of onion and garlic in alloxan-induced diabetic rats. Food Chem Toxicol 2005; 43: 57-63

96 El-Soud NA, Khalil M. Antioxidative effects of Allium cepa essential oil in streptozotocin induced diabetic rats. Macedonia J Med Sci 2010; 3: 344-351

97 Samir AMZ, Somaia ZAR, Mattar AF. Anti-diabetic properties of water and ethanolic extracts of Balanites aegyptiaca fruits flesh in senile diabetic rats. Egypt J Hosp Med 2003; 10: 90-108

98 Gad MZ, El-Sawalhi MM, Ismail MF, El-Tanbouly ND. Biochemical study of the anti-diabetic action of the Egyptian plants fenugreek and balanites. Mol Cell Biochem 2006; 281: 173-183

99 Singh G, Kapoor IP, Pandey SK, Singh UK, Singh RK. Studies on essential oils. Part 10. Antibacterial activity of volatile oils of some spices. Phytother Res 2002; 16: 680-682

100 Eddouks M, Lemhadri A, Michel JB. Caraway and caper: potential antihyperglycaemic plants in diabetic rats. J Ethnopharmacol 2004; 94: $143-148$

101 Lemhadri A, Eddouks M, Michel JB. Cholesterol and triglycerides lowering activities of caraway fruits in normal and streptozotocin diabetic rats. J Ethnopharmacol 2006; 106: 321-326

102 Dawidar AM, Abdel-Mogib M, Abou-Elzahab MM, Berghot MA, Mahfouz $\mathrm{M}$, El-Ghorab AH, Hussien KH. Effect of photo-oxygenation on biological activities of some commercial Egyptian essential oils. Rev Latinoam Quim 2010; 38: 168-179

103 Lemhadri A, Eddouks M, Sulpice T, Burcelin R. Anti-hyperglycaemic and anti-obesity effects of Capparis spinosa and Chamaemelum nobile aqueous extracts in HFD mice. Am J Pharmacol Toxicol 2007; 2: 106110

104 Lemhadri A, Burcelin L, Sulpice T, Eddouks M. Chamaemelum nobile L. aqueous extract represses endogenous glucose production and improves insulin sensitivity in streptozotocin-induced diabetic mice. Am J Pharmacol Toxicol 2007; 2: 116-122

105 Singab ANB, El-Beshbishy HA, Yonekawa M, Nomura T, Fukai T. Hypoglycemic effect of Egyptian Morus alba root bark extract: effect on diabetes and lipid peroxidation of streptozotocin-induced diabetic rats. J Ethnopharmacol 2005; 100: 333-338

106 El-Sayyad HIH, El-Sherbiny MA, Sobh MA, Abou-El-Naga AM, Ibrahim MAN, Mousa SA. Protective effects of Morus alba leaves extract on ocular functions of pups from diabetic and hypercholesterolemic mother rats. Int J Biol Sci 2011; 7: 715-728

107 El-Beshbishy HA, Singab AN, Sinkkonen J, Pihlaja K. Hypolipidemic and antioxidant effects of Morus alba L. (Egyptian mulberry) root bark fractions supplementation in cholesterol-fed rats. Life Sci 2006; 78: 2724-2733

108 Mathur ML, Gaur J, Sharma R, Haldiya KR. Antidiabetic properties of a spice plant Nigella sativa. J Endocrinol Metab 2011; 1: 1-8

109 El-Dakhakhny M, Mady N, Lembert N, Ammon HP. The hypoglycemic effect of Nigella sativa oil is mediated by extrapancreatic actions. Planta Med 2002; 68: 465-466

110 Mohamed AM, EL-Sharkawy FZ, Ahmed SAA, Aziz WM, Badary OA. Glycemic control and therapeutic effect of Nigella sativa and Curcuma longa on rats with streptozotocin-induced diabetic hepatopathy. J Pharmacol Toxicol 2009; 4: 45-57

111 Benhaddou-Andaloussi A, Martineau L, Vuong T, Meddah B, Madiraju P, Settaf A, Haddad PS. The in vivo antidiabetic activity of Nigella sativa is mediated through activation of the AMPK pathway and increased muscle Glut4 content. Evid Based Complement Alternat Med 2011; DOI: $10.1155 / 2011 / 538671$

112 Abdel-Zahera AO, Salima SY, Assaf MH, Abdel-Hady RH. Antidiabetic activity and toxicity of Ziziphus spina-christi leaves. J Ethnopharmacol 2005; 101: 129-138

113 Hala MH, Eman ME, Aataa AS. Antihyperglycemic, antihyperlipidemic and antioxidant effects of Ziziphus spina-christi and Ziziphus jujuba in alloxan induced diabetic rats. Int J Pharmacol 2006; 2: 563-570

114 Michel CG, Nesseem DI, Ismail MF. Anti-diabetic activity and stability study of the formulated leaf extract of Ziziphus spina-christi (L.) Wild with the influence of seasonal variation. J Ethnopharmacol 2011; 133: 53-62

115 Afolayan AJ, Sunmonu TO. Artemisia afra Jacq. ameliorates oxidative stress in the pancreas of streptozotocin-induced diabetic Wistar rats. Biosci Biotechnol Biochem 2011; 75: 2083-2086

116 Afolayan AJ, Sunmonu TO. Protective role of Artemisia afra aqueous extract on tissue antioxidant defense system in streptozotocin-induced diabetic rats. Afr J Tradit Complement Alternat Med 2013; 10: 15-20

117 Ojewale JAO. Antinociceptive, anti-inflammatory and antidiabetic properties of Bryophyllum pinnatum (Crassulaceae) leaf aqueous extract. J Ethnopharmacol 2005; 99: 13-19

118 Mpiana PT, Masunda TA, Longoma BF, Tshibangu DST, Ngbolua KN. Anti-hyperglycemic activity of Raphia gentiliana De Wild. (Arecaceae). Eur J Med Plants 2013; 3: 233-240

119 Ojewole JAO. Hypoglycemic effect of Sclerocarya birrea [(A. Rich.) Hochst.] [Anacardiaceae] stem-bark aqueous extract in rats. Phytomedicine 2003; 10: 675-681

120 Ojewole JAO. Evaluation of the analgesic, anti-inflammatory and antidiabetic properties of Sclerocarya birrea (A. Rich.) Hochst. stem-bark aqueous extract in mice and rats. Phytother Res 2004; 18: 601-608

121 Musabayane CT, Gondwe M, Kamadyaapa DR, Moodley K, Ojewole JAO. The effects of Sclerocarya birrea [(a. rich.) hochst.] [Anacardiaceae] stem-bark aqueous extract on blood glucose, kidney and cardiovascular function in rats. Endocr Abstr 2006; 12: 36

122 Gondwe M, Kamadyaapa DR, Tufts M, Chuturgoon AA, Musabayane CT. Sclerocarya birrea [(A. Rich.) Hochst.] [Anacardiaceae] stem-bark ethanolic extract (SBE) modulates blood glucose, glomerular filtration rate (GFR) and mean arterial blood pressure (MAP) of STZ-induced diabetic rats. Phytomedicine 2008; 15: 699-709

123 Ojewole JAO. Analgesic, anti-inflammatory and hypoglycemic effects of Sutherlandia frutescens R.BR. (variety incana E. MEY.) [Fabaceae] shoot aqueous extract. Methods Find Exp Clin Pharmacol 2004; 26: 409-416

124 Chadwick WA, Roux S, Van de Venter M, Louw J, Oelofsen W. Anti-diabetic effects of Sutherlandia frutescens in Wistar rats fed a diabetogenic diet. J Ethnopharmacol 2007; 109: 121-127

125 MacKenzie J, Koekemoer T, Van de Venter M, Dealtry G, Roux S. Sutherlandia frutescens limits the development of insulin resistance by decreasing plasma free fatty acid levels. Phytother Res 2009; 23: 16091614

126 Nyah NG, Watcho P, Nguelefack T, Kamanyi A. Hypoglycaemic activity of the leaves extracts of Bersama engleriana in rats. Afr J Tradit Complement Alternat Med 2007; 2: 215-221

127 Watcho P, Anchountsa JHG, Mbiakop CU, Nguelefack TB, Kamanyi A, Wankeu-Nya M. Hypoglycemic and hypolipidemic effects of Bersama engleriana leaves in nicotinamide/streptozotocin-induced type 2 diabetic rats. BMC Complement Alternat Med 2012; 12: 264

128 Kuate D, Etoundi BC, Ngondi JL, Oben E. Effects of Dichrostachys glomerata spice on cardiovascular diseases risk factors in normoglycemic and type 2 diabetic obese volunteers. Food Res Int 2011; 44: 11971202

129 Mallidis C, Agbaje I, McClure N, Kliesch S. The influence of diabetes mellitus on male reproductive function: a poorly investigated aspect of male infertility. Urol Assoc 2011; 50: 33-37

130 Wankeu-Nya M, Watcho P, Florea A, Balici S, Matei H, Kamanyi A. Dracena arborea alleviates ultra-structural spermatogenic alterations in streptozotocin-induced diabetic rats. BMC Complement Alternat Med 2013; 13: 71 
131 Kamgang $R$, Mboumi YR, Fondjo AF, Tagne MAF, Mengue N'dille GPR, Yonkeu JN. Antihyperglycaemic potential of the water-extract of $\mathrm{Ka}$ lanchoe crenata (Crassulaceae). J Nat Med 2008; 62: 34-40

132 Fondjo FA, Kamgang R, Oyono JE, Yonkeu JN. Anti-dyslipidemic and antioxidant potentials of methanol extract of Kalanchoe crenata whole plant in streptozotocin-induced diabetic nephropathy in rats. Trop J Pharm Res 2012; 11: 767-775

133 Tamiru W, Engidawork E, Kaleab A. Evaluation of the effects of $80 \%$ methanolic leaf extract of Caylusea abyssinica (Fresen.) fisch. \& Mey. on glucose handling in normal, glucose loaded and diabetic rodents. BMC Complement Alternat Med 2012; 12: 151

134 Piero NM, Murugi NJ, Kibiti MC, Ngeranwa JJ, Njue MW, Maina D, Gathumbi KP, Njagi NE. Hypoglycemic activity of some Kenyan plants traditionally used to manage diabetes mellitus in eastern province. J Diabet Metab 2011; 2: 1-6

135 Leung L, Birtwhistle R, Kotecha J. Anti-diabetic and hypoglycaemic effects of Momordica charantia (bitter melon): a mini review. Br J Nutr 2009; 102: 1703-1708

136 Matheka DM, Kiama TN, Alkizim FO, Bukachi F. Glucose-lowering effects of Momordica charantia in healthy rats. Afr J Diabet Med 2011; 19: $15-19$

137 Nardos A, Makonnen E, Debella A. Effects of crude extracts and fractions of Moringa stenopetala (Baker f) Cufodontis leaves in normoglycemic and alloxan-induced diabetic mice. Afr J Pharm Pharmacol 2011; 5: 2220-2225

138 Toma A, Makonnen E, Debella A, Tesfaye B. Antihyperglycemic effect on chronic administration of butanol fraction of ethanol extract of Moringa stenopetala leaves in alloxan induced diabetic mice. Asian Pac J Trop Biomed 2012; 2: 606-610

139 Salisu Y, Agunu A, Abubakar MS, Ibrahim G. Hypoglycaemic effects of Acacia albida Del. (Mimosaceae) methanol root bark extract. Niger J Pharm Sci 2009; 8: 66-72

140 Ikewuchi J, Onyeike EN, Uwakwe AA, Ikewuchi CC. Effect of aqueous extract of the leaves of Acalypha wilkesiana 'Godseffiana' Muell. Arg. (Euphorbiaceae) on the hematology, plasma biochemistry and ocular indices of oxidative stress in alloxan induced diabetic rats. J Ethnopharmacol 2011; 137: 1415-1424

141 Tanko Y, Yerima M, Mahdi MA, Yaro AH, Musa KY, Mohammed A. Hypoglycemic activity of methanolic stem bark of Adansonia digitata extract on blood glucose levels of streptozotocin-induced diabetic Wistar rats. Int J Appl Res Nat Prod 2008; 1: 32-36

142 Odo RI, Asuzu IU, Aba PE. The antidiabetic activities of the methanolic root bark extract of Afzelia africana in alloxan-induced diabetic mice. J Complement Integr Med 2012; 9: 1-11

143 Egunyomi A, Gbadamosi IT, Animashahun MO. Hypoglycaemic activity of the ethanol extract of Ageratum conyzoides Linn. shoots on alloxaninduced diabetic rats. J Med Plants Res 2011; 5: 5347-5350

144 Agunbiade OS, Ojezele OM, Ojezele JO, Ajayi AY. Hypoglycaemic activity of Commelina africana and Ageratum conyzoides in relation to their mineral composition. Afr Health Sci 2012; 12: 198-203

145 Mohammed RK, Ibrahim S, Atawodi SE, Eze ED, Suleiman JB. Anti-diabetic and haematological effects of n-butanol fraction of Alchornea cordifolia leaf extract in streptozotocin-induced diabetic Wistar rats. Glob J Med Plant Res 2012; 1: 14-21

146 Ozougwu JC. Anti-diabetic effects of Allium cepa (onions) aqueous extracts on alloxan-induced diabetic Rattus novergicus. J Med Plants Res 2011; 5: 1134-1139

147 Obi HI, Ilodigwe EE, Ajaghaku DE, Okonta JM. The antidiabetic activity of combine aqueous extracts of Gongronema latifolium (Benth) and Allium cepa. J Pharm Biomed Sci 2012; 19: 1-5

148 Yusuf UA, Adeeyo OA, Salawu EA, Enaibe BU, Omotoso OD. Allium cepa protects renal functions in diabetic rabbits. World J Life Sci Med Res 2012; 2: 86-90

149 Ogunmodede OS, Saalu LC, Ogunlade B, Akunna GG, Oyewopo AO. An evaluation of hypoglycemic, antioxidant and hepatoprotective potentials of Onion (Allium cepa L.) on alloxan-induced diabetic rabbits. Int J Pharmacol 2012; 8: 21-29

150 Ojo RJ, Memudu AE, Akintayo CO, Akpan IS. Preventive effect of Allium sativum on alloxan induced diabetic rat. ARPN J Agric Biol Sci 2012; 7 : 609-612

151 Saidu AN, Mann A, Balogun S. The hypoglycemic effect of aqueous extract of the Anacardium occidentale Linn leaves grown in Nigeria on normoglycemic albino rats. J Emerg Trends Eng Appl Sci 2012; 3: 302-308
152 Sani D, Sanni S, Ngulde SI. Hypoglycaemic effect of aqueous stem extract of Anisopus mannii in normal rats. Afr J Pharm Pharmacol 2009; 3: $481-484$

153 Manosroi J, Zaruwa MZ, Manosroi A. Potent hypoglycemic effect of Nigerian anti-diabetic medicinal plants. J Complement Integr Med 2011; DOI: $10.2202 / 1553-3840.1482$

154 Olubomehin OO, Abo KA, Ajaiyeoba EO. Alpha-amylase inhibitory activity of two Anthocleista species and in vivo rat model anti-diabetic activities of Anthocleista djalonensis extracts and fractions. J Ethnopharmacol 2013; 146: 811-814

155 Ibeh BO, Ezeaja M. Preliminary study of antidiabetic activity of the methanolic leaf extract of Axonopus compressus (P. Beauv) in alloxaninduced diabetic rats. J Ethnopharmacol 2011; 138: 713-716

156 Aguh BI, Nock IH, Ndams IS, Agunu A. Hypoglycaemic activity and Nephro-protective effect of Bauhinia rufescens in alloxan-induced diabetic rats. Int J Appl Pharm Biol Chem 2013; 2: 249-255

157 Aguh BI, Nock IH, Ndams IS, Agunu A, Ayeku PO. Hypolipidemic properties of Bauhinia rufescens in alloxan-induced diabetic rats. Sci J Biol Sci 2013; 2: 68-75

158 Kolawole OM, Oladoyinbo SO, Agbede OO, Adu FD. The effect of Bridelia ferruginea and Senna alata on plasma glucose concentrationin normoglycemic and glucose induced hyperglycemic rats. Ethnobot Leaflets 2006; 10: 209-218

159 Adeneye AA, Olagunju AA. Preliminary hypoglycemic and hypolipidemic activities of the aqueous seed extract of Carica papaya Linn. in Wistar rats. Biol Med 2009; 1: 1-10

160 Osadolor HB, Ariyo II, Emokpae MA, Anukam KC. Hypoglycemic effect of unripe pawpaw on streptozotocin induced diabetic albino rats. Res J Med Plants 2011; 5: 90-94

161 Ene AC, Milala MA, Nwankwo EA. The effect of different doses of black caraway (Carum carvi L.) oil on the liver enzymes of alloxan-induced diabetic rats. J Med Sci 2006; 6: 994-998

162 Ene AC, Bukbuk DN, Ogunmola OO. The effect of different doses of black caraway (Carum carvi L.) oil on the serum creatinine of alloxan-induced diabetic rats. J Med Sci 2006; 6: 701-703

163 Ene AC, Nwankwo EA, Samdi LM. Alloxan-induced diabetic rats and the effects of black caraway (Carum carvi L.) oil on their body weight. Res J Med Med Sci 2007; 2: 48-52

164 Ene AC, Nwankwo EA, Samdi LM. Alloxan-induced diabetic rats and the effects of black caraway (Carum carvi L.) oil on their body weight. J Pharmacol Toxicol 2007; 3: 141-146

165 Nadro MS. Hypoglycaemic effects of Cassia italica leaf extracts on streptozotocin-induced diabetic albino rats. J Res Biosci 2009; 6: 3841

166 Nadro MS, Onoagbe IO. Anti-hyperlipidaemic and antioxidant effect of aqueous and ethanolic extracts of Cassia italica leaves in streptozotocin-induced diabetes in rats. J Med Plants Res 2012; 6: 4675-4681

167 Emeka EJI, Clement UO. Comparative study of hypoglycemic and biochemical effects of Catharantus roseus (Linn.), apocyanaceae (Madagascar periwinkle) and chlorpropamide (diabenese) on alloxan induced diabetic rats. Biokemistri 2005; 7: 149-156

168 Ladeji O, Omekarah I, Solomon M. Hypoglycemic properties of aqueous bark extract of Ceiba pentandra in streptozotocin-induced diabetic rats. J Ethnopharmacol 2002; 84: 139-142

169 N'guessan K, Amoikon KE, Tiébré MS, Kadja B, Zirihi GN. Effect of aqueous extract of Chrysophyllum cainito leaves on the glycaemia of diabetic rabbits. Afr J Pharm Pharmacol 2009; 3: 501-506

170 Ezekwesili CN, Ogbunugafor HA, Ezekwesili-Ofili JO. Anti-diabetic activity of aqueous extracts of Vitex doniana leaves and Cinchona calisaya bark in alloxan-induced diabetic rats. Int J Trop Dis Health 2012; 2: 290-300

171 Tanko Y, Yaro AH, Isa AI, Yerima M, Saleh MIA, Mohammed A. Toxicological and hypoglycemic studies on the leaves of Cissampelos mucronata (Menispermaceae) on blood glucose levels of streptozotocin-induced diabetic Wistar rats. J Med Plants Res 2007; 1: 113-116

172 Ekeanyanwu RC, Udeme AA, Onuigbo AO, Etienajirhevwe OF. Anti-diabetic effect of ethanol leaf extract of Cissampelos owariensis (lungwort) on alloxan induced diabetic rats. Afr J Biotechnol 2012; 11: 6758-6762

173 Opajobi AO, Esume CO, Campbell P, Onyesom I, Osasuyi A. Effects of aqueous extracts of Rauvolfia vomitoria and Citrus aurantium on liver enzymes of streptozotocin - induced diabetic and normal rabbits. Cont J Med Res 2011; 5: 1-5 
174 Adeneye $A A$. Hypoglycemic and hypolipidemic effects of methanol seed extract of Citrus paradisi Macfad (Rutaceae) in alloxan-induced diabetic Wistar rats. Niger Q J Hosp Med 2008; 18: 211-215

175 Adebajo AC, Iwalewa EO, Obuotor EM, Ibikunle GF, Omisore NO, Adewunmi CO, Obaparusi OO, Klaes M, Adetogun GE, Schmidt TJ, Verspoh EJ. Pharmacological properties of the extract and some isolated compounds of Clausena lansium stem bark: anti-trichomonal, antidiabetic, anti-inflammatory, hepatoprotective and antioxidant effects. J Ethnopharmacol 2009; 122: 10-19

176 Adisa RA, Choudhary MI, Adewoye EO, Olorunsogo OO. Hypoglyceamic and biochemical properties of Cnestis ferruginea. Afr J Tradit Complement Alternat Med 2010; 7: 185-194

177 Chika A, Bello SO. Antihyperglycaemic activity of aqueous leaf extract of Combretum micranthum (Combretaceae) in normal and alloxan-induced diabetic rats. J Ethnopharmacol 2010; 129: 34-37

178 Sarah N, Oluwatosin A, Ajaiyeoba E. Oral administration of extract from Curcumin longa lowers blood glucose and attenuates alloxan-induced hyperlipidemia in diabetic rabbits. Pak J Biol Sci 2009; 8: 625628

179 Iwueke AV, Nwodo OFC. Effect of combined root extract of Sarcocephalus latifolius and Daniella oliveri on blood glucose and serum lipids in alloxan-diabetic rats. Niger J Biochem Mol Biol 2008; 23: 37-41

180 Iwueke AV, Nwodo OFC. Antihyperglycaemic effect of aqueous extract of Daniella oliveri and Sarcocephalus latifolius roots on key carbohydrate metabolic enzymes and glycogen in experimental diabetes. Biokemistri 2008; 20: 63-70

181 Omoniwa BP, Luka CD. Antidiabetic and toxicity evaluation of aqueous stem extract of Ficus asperifolia in normal and alloxan-induced diabetic rats. Asian J Exp Biol Sci 2012; 3: 726-732

182 Adeyi AO, Idowu AB, Mafiana CF, Oluwalana SA, Ajayi OL. Effects of aqueous leave extract of Ficus exasperata on pathophysiology and histopathology of alloxan-induced diabetic albino rats. J Med Plants Res 2012; 6: 5730-5736

183 Adewole SO, Adenowo TK, Thajasvarie N, Ojewole AO. Hypoglycaemic and hypotensive effects of Ficus exasperata VAHL. (Moraceae) leaf aqueous extract in rats. Afr J Tradit Complement Alternat Med 2011; 8: 275-283

184 Mohammed A, Adelaiye AB, Bakari AG, Mabrouk MA. Anti-diabetic and some haematological effects of ethylacetate and n-butanol fractions of Ganoderma lucidum aqueous extract in alloxan-induced diabetic Wister rats. Int J Med Med Sci 2009; 1: 530-535

185 Gnangoran BN, N'guessan BB, Amoateng P, Dosso K, Yapo AP, Ehile EE. Hypoglycaemic activity of ethanolic leaf extract and fractions of $\mathrm{Ho}$ larrhena floribunda (Apocynaceae). J Med Biomed Sci 2012; 1: 46-54

186 Okokon JE, Bassey SA, Basil NI. Antidiabetic effects of Homalium letestui (Flacourtiaceae) in streptozotocin induced diabetic rats. Res J Med Plant 2007; 1: 134-138

187 Adeneye AA, Adeyemi 00. Further evaluation of antihyperglycaemic activity of Hunteria umbellata (K. Schum) Hallier f. seed extract in experimental diabetes. J Ethnopharmacol 2009; 126: 238-243

188 Ezeigbo II, Asuzu IU. Anti-diabetic activities of methanol leaf extract of Hymenocardia acida (TUL.) in alloxan-induced diabetic rats. Afr J Tradit Complement Alternat Med 2012; 9: 204-209

189 Danmalam UH, Abdullahi LM, Agunu A, Musa KY. Acute toxicity studies and hypoglycemic activity of the methanol extract of the leaves of $\mathrm{Hy}$ ptis suaveolens Poit. (Lamiaceae). Niger J Pharm Sci 2009; 8: 87-92

190 Omonkhua AA, Onoagbe IO. Effects of long-term oral administration of aqueous extracts of Irvingia gabonensis bark on blood glucose and liver profile of normal rabbits. J Med Plants Res 2012; 6: 2581-2589

191 Momoh MA, Muhammed $U$. Toxicological and hypoglycemic studies on the oil extracted from seeds of Khaya senegalensis on blood glucose levels of alloxan-induced diabetic albino rats. J Med Plants Res 2011; 5: 4021-4024

192 Kolawole OT, Kolawole SO, Ayankunle AA, Olaniran OI. Anti-hyperglycemic effect of Khaya senegalensis stem bark aqueous extract in Wistar rats. Eur J Med Plants 2012; 2: 66-73

193 Bello A, Aliero AA, Saidu Y, Muhammad S. Hypoglycaemic and hypolipidaemic effects of Leptadenia hastata (Pers.) Decne in alloxan induced diabetic rats. Niger J Basic Appl Sci 2011; 19: 187-192

194 Osadebe PO, Omeje EO, Nworu SC, Esimone CO, Uzor PF, David EK, Uzoma JU. Antidiabetic principles of Loranthus micranthus Linn. parasitic on Persea americana. Asian Pac J Trop Biomed 2010; 3: 619-623

195 Osadebe PO, Omeje EO, Uzor PF, David EK, Obiorah DC. Seasonal variation for the antidiabetic activity of Loranthus micranthus methanol extract. Asian Pac J Trop Biomed 2010; 3: 196-199
196 Ugbenyen AM, Odetola AA. Hypoglycemic potential of the young leaves methanolic extract of Magnifera indica in alloxan induced diabetic rats. Pak J Nutr 2009; 8: 239-241

197 Okokon JE, Bassey SA, Osuji LC, Pius MU. Antidiabetic and hypolipidemic effect of Mammea africana (Guttiferae) in streptozotocin induced diabetic rats. J Pharmacol Toxicol 2007; 2: 278-283

198 Enomfo JA, Okokon JE, Offong E. Antidiabetic and hypolipidemic activities of ethanolic leaf extract and fractions of Melanthera scandens Asian Pac J Trop Biomed 2012; 2: 523-527

199 Ataman JE, Grillo DB, Omongbai EKI, Idu M, Amaechina F, Okonji V, Ayinde BA. Effect of methanolic extract of Momordica charantia leaves on alloxan treated Wistar rats. J Med Sci 2006; 6: 828-832

200 Tarkang PA, Ofogba CJ. Evaluation of the hypoglycemic activity and safety of Momordica charantia (Cucurbitaceae). Afr J Pharm Sci Pharm 2012; 3: 17-29

201 Odutuga AA, Dairo JO, Minari JB, Bamisaye FA. Ant-diabetic effect of Morinda lucida stem bark extracts on alloxan induced diabetic rats. Res J Pharmacol 2010; 4: 78-82

202 Adeneye AA, Agbaje EO. Pharmacological evaluation of oral hypoglycemic and antidiabetic effects of fresh leaves ethanol extract of Morinda lucida Benth. in normal and alloxan induced diabetic rats. Afr J Biomed Res 2008; 11: 65-71

203 Edoga CO, Njoku OO, Amadi EN, Okeke JJ. Blood sugar lowering effect of Moringa oleifera Lam in albino rats. Int J Sci Technol 2013; 3: 88-90

204 Salau BA, Ajani EO. Methanolic extract of Musa sapientum (L var. paradisiacal) sucker improves lipid profiles in alloxan induced diabetic rats. Asian J Biol Sci 2012; 5: 322-327

205 Adewoye EO, Ige AO, Latona CT. Effect of methanolic extract of Musa sapientum leaves on gastrointestinal transit time in normal and alloxan induced diabetic rats: possible mechanism of action. Niger J Physiol Sci 2011; 26: 083-088

206 Adeneye AA, Ajagbonna OP, Ayodele OW. Hypoglycemic and antidiabetic activities on the stem bark aqueous and ethanol extracts of $\mathrm{Mu}$ sanga cecropioides in normal and alloxan-induced diabetic rats. Fitoterapia 2007; 78: 502-505

207 Owolabi OJ, Amaechina FC, Okoro M. Effect of ethanol leaf extract of Newbouldia laevis on blood glucose levels of diabetic rats. Trop J Pharm Res 2011; 10: 249-254

208 Umar IA, Mohammed A, Dawud FA, Kyari H, Abdullahi M. Anti-diabetic action of the aqueous extract of Ocimum suave in alloxan-induced diabetic rats. Afr J Biotechnol 2012; 11: 9243-9247

209 Igbakin AP, Adanlawo IG. The effect of solvent extracts of Parimari microphylla on metabolites of alloxan induced diabetic rats. Int J Biol Chem 2009; 3: 49-55

210 Ndiaye M, Diatta W, Sy AN, Dieye AM, Faye B, Bassene E. Antidiabetic properties of aqueous barks extract of Parinari excelsa in alloxan-induced diabetic rats. Fitoterapia 2008; 79: 267-270

211 Odetola AA, Akinloye O, Egunjobi C, Adekunle WA, Ayoola AO. Possible antidiabetic and antihyperlipidaemic effect of fermented Parkia biglobosa (Jacq) extract in alloxan-induced diabetic rats. Clin Exp Pharmacol Physiol 2006; 33: 808-812

212 Saba AB, Oyagbemi AA, Azeez OI. Antidiabetic and haematinic effects of Parquetina nigrescens on alloxan induced type-1 diabetes and normocytic normochromic anaemia in Wistar rats. Afr Health Sci 2010; 10: $276-282$

213 Edem DO. Hypoglycemic effects of ethanolic extracts of alligator pear seed (Persea americana Mill) in rats. Eur J Sci Res 2009; 33: 669-678

214 Nwanjo HU, Oze G, Okafor MC, Nwosu D, Nwankpa P. Protective role of Phyllanthus niruri extract on serum lipid profiles and oxidative stress in hepatocytes of diabetic rats. Afr J Biotechnol 2007; 6: 1744-1749

215 Mbaka GO, Ogbonnia SO, Oyeniran KJ, Awopetu PI. Effect of Raphia hookeri seed extract on blood glucose, glycosylated haemoglobin and lipid profile of alloxan induced diabetic rats. Br J Med Med Res 2012; 2: 621-635

216 Ikewuchi JC, Ikewuchi CC. Hypoglycemic, hypocholesterolemic and ocular-protective effects of an aqueous extract of the rhizomes of Sansevieria senegambica baker (Agavaceae) on alloxan-induced diabetic Wister rats. Am J Biochem Mol Biol 2012; 2: 48-66

217 Onakpa MM, Ajagbonna OP. Antidiabetic potentials of Cassia occidentalis leaf extract on alloxan induced diabetic albino mice. Int J PharmTech Res 2012; 4: 1766-1769

218 Mohammed A, Atiku MK. Anti-hyperglycemic and anti-hyperlipidemic effect of leaves and stem bark methanol extracts of Senna siamea in alloxan induced diabetic rats. Curr Res Cardiovasc Pharmacol 2012; 1: $10-17$ 
219 Odason EE, Kolawole JA. Anti-diabetic properties and brine shrimp toxicity of the aqueous extract of the root of Cassia siamea Lam (Ceasalpiniaceae). Niger J Pharm Res 2007; 6: 66-69

220 Okokon JE, Bassey AL, Nwidu LL. Antidiabetic and hypolipidemic effects of ethanolic root extract of Setaria megaphylla. Int J Pharmacol 2007; 3: 91-95

221 Martins E, Adesina 00, Adewale GB, Kolawole SO, Tomilola EJ, Oyemayowa VS. Comparative evaluation of the protective effect of ethanolic and methanolic leaf extracts of Sida acuta against hyperglycaemia and alterations of biochemical and haematological indices in alloxan induced diabetic rats. J Pharmacol Toxicol 2010; 5: 1-12

222 Kade IJ, Barbosa NBV, Ibukun EO, Igbakin AP, Nogueira CW, Rocha JBT. Aqueous extracts of Sphagneticola trilobata attenuates streptozotocin-induced hyperglycaemia in rat models by modulating oxidative stress parameters. Biol Med 2010; 2: 1-13

223 Godwin M, Adeyemi O, Osinubi A, Noronha C, Okanlawon A. The effect of aqueous root extract of Sphenocentrum jollyanum on blood glucose level of rabbits. J Med Plants Res 2009; 3: 870-874

224 Isah AB, Ibrahim YKE, Abdulrahman EM, Ibrahim MA. The hypoglycaemic activity of the aqueous extract of Stachytarpheta angustifolia (Verbanaceae) in normoglycaemic and alloxan-induced diabetic rats. Pak J Biol Sci 2007; 10: 137-141

225 Olorunfemi AE, Patrick E, Arit E, Arnold I, Emmanuel O. Hypoglycemic effect of the seed extract of Telfairia occidentalis in rats. Pak J Biol Sci 2007; 10: 498-501

226 Teugwa CW, Boudjeko T, Tchinda BT, Mejiato PC, Zofou D. Anti-hyperglycaemic globulins from selected Cucurbitaceae seeds used as antidiabetic medicinal plants in Africa. BMC Complement Alternat Med 2013; 13: 2-8

227 N'guessan K, Fofie NBY, Zirihi GN. Effect of aqueous extract of Terminalia catappa leaves on the glycaemia of rabbits. J Appl Pharm Sci 2011; 1: 59-64

228 Kingsley O, Iyere OO, Georgina EO, Esosa US, Kazeem AO, Frank AO. Effects of aqueous root extract of Treculia africana on blood glucose, lipid profile and body weight changes of streptozotocin-induced diabetic and normal rats. Int J Plant Physiol Biochem 2011; 3: 169-175

229 Prohp TP, Onoagbe IO. Anti-diabetic properties and toxicological studies of Triplochiton scleroxylon on the heart enzymes in normal and streptozotocin-induced diabetic rabbits. Pak J Nutr 2009; 8: 10251029

230 Sy GY, Cissé A, Nongonierma RB, Sarr M, Mbodj NA, Faye B. Hypoglycaemic and antidiabetic activity of acetonic extract of Vernonia colorata leaves in normoglycaemic and alloxan-induced diabetic rats. J Ethnopharmacol 2005; 98: 171-175

231 Adaramoye O, Amanlou M, Habibi-Razaei M, Pasalar P, Moosavi-Movahedi A. Methanolic extract of African mistletoe (Viscum album) improves carbohydrate metabolism and hyperlipidemia in streptozotocin-induced diabetic rats. Asian Pac J Trop Biomed 2012; 5: 427-433

232 Ngugi MP, Murugi NJ, Kibiti MC, Ngeranwa JJ, Njue MW, Maina D, Gathumbi KP, Njagi NE. Hypoglycemic activity of some Kenyan plants traditionally used to manage diabetes mellitus in Eastern province. J Diabetes Metab 2011; 2: 1-6

233 Njagi JM, Piero MN, Ngeranwa JJN, Njagi ENM, Kibiti CM, Njue WM, Maina D, Gathumbi PK. Assessment of antidiabetic potential of Ficus sycomorus on alloxan-induced diabetic mice. Int J Diabet Res 2012; 1: 47-51

234 Karau GM, Njagi ENM, Machocho AK, Wangai LN, Kamau PN. Hypoglycemic activity of aqueous and ethylacetate leaf and stem bark extracts of Pappea capensis in alloxan-induced diabetic BALB/C mice. $\mathrm{Br}$ J Pharmacol Toxicol 2012; 3: 251-258

235 Dinku T, Tadesse S, Asres $K$. Antidiabetic activity of the leafextracts of Pentas schimperiana subsp. schimperiana (A. Rich) Vatke on alloxaninduced diabetic mice. Ethiop Pharm J 2010; 28: 22-26

236 Kambouche N, Merah B, Derdour A, Bellahouel S, Bouayed J, Dicko A, Younos $C$, Soulimani R. Hypoglycemic and antihyperglycemic effects of Anabasis articulata (Forssk) Moq (Chenopodiaceae), an Algerian medicinal plant. Afr J Biotechnol 2009; 8: 5578-5583

237 Hamza N, Berkea B, Chezea C, Aglib A, Robinsona P, Ginc H, Moore N. Prevention of type 2 diabetes induced by high fat diet in the C57BL/ 6J mouse by two medicinal plants used in traditional treatment of diabetes in the east of Algeria. J Ethnopharmacol 2010; 128: 513-518

238 Eddouks M, Lemhadri A, Michel JB. Hypolipidemic activity of aqueous extract of Capparis spinosa L. in normal and diabetic rats. J Ethnopharmacol 2005; 98: 345-350
239 Sefi M, Fetoui H, Lachkar N, Tahraoui A, Lyoussi B, Zeghal N, Boudawara T. Centaurium erythrea (Gentianaceae) leaf extract alleviates streptozotocin-induced oxidative stress and $\beta$-cell damage in rat pancreas. J Ethnopharmacol 2011; 135: 243-250

240 Mohammed MS, Hossam FA, Samir AE, Osama MS. Biomedical effect of cinnamon extract on obesity and diabetes relevance in Wistar rats. Am J Biochem Mol Biol 2012; 2: 133-145

241 Nahla SE, Ismail MA. Hypoglycemic effect of Cleome droserifolia ethanolic leaf extract in experimental diabetes and on non-enzymatic antioxidant, glycogen, thyroid hormone and insulin levels. Diabetol Croat 2006; 35: 15-22

242 Mohamed A. Antidiabetic, antihyperlipidemic and antioxidant effects of aqueous of the roots of Cynara cornigera in alloxan induced experimental diabetic rats. Int J Pharmacol 2011; 7: 782-789

243 Houacine C, Elkhawad AO, Ayoub SMH. A comparative study on the anti-diabetic activity of extracts of some Algerian and Sudanese plants. J Diabet Endocrinol 2012; 3: 25-28

244 Jouad H, Maghrani M, Eddouks M. Hypoglycaemic effect of Rubus fructicosis L. and Globularia alypum L. in normal and streptozotocin-induced diabetic rats. J Ethnopharmacol 2002; 81: 351-356

245 Zeggwagh NA, Eddouks M, Lemhadri A. Study of hypoglycaemic and hypolipidemic effects of Inula viscosa L. aqueous extract in normal and diabetic rats. J Ethnopharmacol 2006; 108: 223-227

246 Eddouks M, Maghrani M, Michel JB, Zeggwagh NA. Study of the hypoglycaemic activity of Lepidium sativum $\mathrm{L}$. aqueous extract in normal and diabetic rats. J Ethnopharmacol 2005; 97: 391-395

247 Sayed MR, Mourad IM, Sayed DA. Biochemical changes in experimental diabetes before and after treatment with Mangifera indica and Psidium guajava extracts. Int J Pharm Biomed Sci 2011; 2: 29-41

248 Zeggwagh NA, Sulpice T, Eddouks M. Anti-hyperglycaemic and hypolidemic effects of Ocimum basilicum aqueous extract in diabetic rats. Am J Pharmacol Toxicol 2007; 2: 123-129

249 El-Khayat Z, Hussein J, Ramzy T, Ashour M. Antidiabetic antioxidant effect of Panax ginseng. J Med Plants Res 2011; 5: 4616-4620

250 Jouad H, Eddouks M, Lacaille-Dubois MA, Lyoussi B. Hypoglycaemic effect of Spergularia purpurea in normal and streptozotocin-induced diabetic rats. J Ethnopharmacol 2000; 71: 169-177

251 Jouad H, Lemhadri A, Maghrani M, Zeggwagh NA, Eddouks M. Cholesterol-lowering activity of the aqueous extract of Spergularia purpurea in normal and recent-onset diabetic rats. J Ethnopharmacol 2003; 87: 43-49

252 Benwahhoud M, Jouad H, Eddouks M, Lyoussia B. Hypoglycemic effect of Suaeda fruticosa in streptozotocin-induced diabetic rats. J Ethnopharmacol 2001; 76: 35-38

253 El Amrani F, Rhallab A, Alaoui T, El Badaoui E, Chakir S. Hypoglycaemic effect of Thymelaea hirsuta in normal and streptozotocin-induced diabetic rats. J Med Plants Res 2009; 3: 625-629

254 Eddouks M, Maghrani M, Michel JB. Hypoglycaemic effect of Triticum repens $\mathrm{P}$. Beauv. in normal and diabetic rats. J Ethnopharmacol 2005; 102: 228-232

255 Abd-Elraheem AE, Muhammad MAS, Mahrous MAM. Effect of ginger extract consumption on levels of blood glucose, lipid profile and kidney functions in Alloxan induced-diabetic rats. Egypt Acad J Biol Sci 2009; 2 : 153-162

256 Oyedemi SO, Adewusi EA, Aiyegoro OA, Akinpelu DA. Antidiabetic and haematological effect of aqueous extract of stem bark of Afzelia africana (Smith) on streptozotocin-induced diabetic Wistar rats. Asian Pac J Trop Biomed 2011; 1: 353-358

257 Islam MS, Choi H, Loots DT. Effects of dietary onion (Allium cepa L.) in a high-fat diet streptozotocin-induced diabetes rodent model. Ann Nutr Metab 2008; 53: 6-12

258 Gundidza M, Masuku S, Humphrey G, Magwa ML. Anti-diabetic activity of Aloe excelsa. Cent Afr J Med 2005; 51: 115-120

259 Loots DT, Pieters M, Islam MS, Botes L. Antidiabetic effects of Aloe ferox and Aloe greatheadii var. davyana leaf gel extracts in a low-dose streptozotocin diabetes rat model. S Afr J Sci 2011; 107: 1-6

260 Mellem JJ, Baijnath H, Odhav B. Effect of the methanolic extract of Brachylaena discolor in a streptozotocin-induced diabetic rat model. Afr J Pharm Pharmacol 2013; 7: 636-642

261 Islam MS. Effects of the aqueous extract of white tea (Camellia sinensis) in a streptozotocin-induced diabetes model of rats. Phytomedicine 2011; 19: 25-31

262 Ojewole JAO. Hypoglycaemic effect of Clausena anisata (Wild) Hook methanolic root extract in rats. J Ethnopharmacol 2002; 81: 231-237 
263 Ojewole JAO, Adewunmi CO. Hypoglycaemic effects of methanolic leaf extract of Catharanthus roseus (Linn.) G. Don (Apocynaceae) in normal and diabetic mice. Acta Med Biol 2000; 48: 55-58

264 Deutschländer MS, Lall N, Van de Venter M, Hussein AA. Hypoglycemic evaluation of a new triterpene and other compounds isolated from Euclea undulata Thunb. var. myrtina (Ebenaceae) root bark. J Ethnopharmacol 2011; 133: 1091-1095

265 Ojewale JAO. Antinociceptive, anti-inflammatory and antidiabetic properties of Hypoxis hemerocallidea Fisch. \& C.A. Mey. (Hypoxidaceae) corm ['African Potato'] aqueous extract in mice and rats. J Ethnopharmacol 2006; 103: 126-134

266 Mahomed IM, Ojewole JA. Hypoglycemic effect of Hypoxis hemerocallidea corm (African potato) aqueous extract in rats. Methods Findings Exp Clin Pharmacol 2003; 25: 617-623

267 Oyedemi SO, Yakubu MT, Afolayan AJ. Antidiabetic activities of aqueous leaves extract of Leonotis leonurus in streptozotocin induced diabetic rats. J Med Plants Res 2011; 5: 119-125

268 Dzeufiet PDD, Ohandja DY, Tédong L, Asongalem EA, Dimo T, Sokeng SD, Kamtchouing $P$. Antidiabetic effect of Ceiba pentandra extract on streptozotocin-induced non-insulin-dependent diabetic (NIDDM) rats. Afr J Tradit Complement Alternat Med 2007; 4: 47-54

269 George C, Lochner A, Huisamen B. The efficacy of Prosopis glandulosa as antidiabetic treatment in rat models of diabetes and insulin resistance. J Ethnopharmacol 2011; 137: 298-304

270 Ojewole JA. Hypoglycemic and hypotensive effects of Psidium guajava Linn. (Myrtaceae) leaf aqueous extract. Methods Findings Exp Clin Pharmacol 2005; 27: 689-695
271 Ojewole JAO. Analgesic, anti-inflammatory and hypoglycaemic effects of Rhus chirindensis (Baker F.) [Anacardiaceae] stem-bark aqueous extract in mice and rats. J Ethnopharmacol 2007; 113: 338-345

272 Oyedemi SO, Bradley G, Afolayan AJ. Beneficial effect of aqueous extracts of Strychnos henningsii Gilg in streptozotocin-nicotinamide induced type 2 diabetic Wistar rats. Int J Pharmacol 2011; 7: 773-781

273 Sokeng SD, Lontsi D, Moundipa PF, Jatsa HB, Watcho P, Kamtchouing P. Hypoglycemic effect of Anacardium occidentale L. methanol extract and fractions on streptozotocin-induced diabetic rats. Glob J Pharmacol 2007; $1: 1-5$

274 Kamtchouing P, Kahpui SM, Dzeufiet D, Tédong L, Asongalem EA, Dimo T. Anti-diabetic activity of methanol/methylene chloride stem bark extracts of Terminalia superba and Canarium schweinfurthii on streptozotocin-induced diabetic rats. J Ethnopharmacol 2006; 104: 306-309

275 Dimo T, Rakotonirina SV, Tan PV, Azay J, Dongo E, Kamtchouing P, Cros G. Effect of Sclerocarya birrea (Anacardiaceae) stem bark methylene chloride/methanol extract on streptozotocin-diabetic rats. J Ethnopharmacol 2007; 110: 434-438

276 Makom IGN, Frigerio F, Casimir M, Ngueguim FT, Dongo E, Kamtchouing P, Dimo T, Maechler P. Sclerocarya birrea (Anacardiaceae) stem-bark extract corrects glycaemia in diabetic rats and acts on beta-cells by enhancing glucose-stimulated insulin secretion. J Endocrinol 2010; 205: 79-86

277 Ojewole JAO, Adewole SO, Olayiwola G. Hypoglycaemic and hypotensive effects of Momordica charantia Linn (Cucurbitaceae) whole-plant aqueous extract in rats. Cardivasc J S Afr 2006; 17: 227-232 